\title{
Steric and Electronic Control over the Reactivity of a Thiolate- Ligated Fe(II) Complex with Dioxygen and Superoxide: Reversible $\mu$-Oxo Dimer Formation
}

\author{
Roslyn M. Theisen, Jason Shearer, Werner Kaminsky ${ }^{\dagger}$, and Julie A. Kovacs* \\ Department of Chemistry, University of Washington, Box 351700, Seattle, Washington \\ 98195-1700
}

\section{Abstract}

The reactivity between a thiolate-ligated five-coordinate complex $\left[\mathrm{Fe}^{\mathrm{II}}\left(\mathrm{S}^{\mathrm{Me} 2} \mathrm{~N}_{4}(\operatorname{tren})\right)\right]^{+}(\mathbf{1})$ and dioxygen is examined in order to determine if $\mathrm{O}_{2}$ activation, resembling that of the metalloenzyme cytochrome $\mathrm{P} 450$, can be promoted even when $\mathrm{O}_{2}$ binds cis, as opposed to trans, to a thiolate. Previous work in our group showed that $\left[\mathrm{Fe}^{\mathrm{II}}\left(\mathrm{S}^{\mathrm{Me} 2} \mathrm{~N}_{4} \text {-(tren) }\right)\right]^{+}(\mathbf{1})$ reacts readily with superoxide $\left(\mathrm{O}_{2}^{-}\right)$in the presence of a proton source to afford $\mathrm{H}_{2} \mathrm{O}_{2}$ via an $\mathrm{Fe}^{\mathrm{III}}-\mathrm{OOH}$ intermediate, thus providing a biomimetic model for the metalloenzyme superoxide reductase (SOR). Addition of $\mathrm{O}_{2}$ to 1 affords binuclear $\mu$-oxo-bridged $\left[\mathrm{Fe}^{\mathrm{III}}\left(\mathrm{S}^{\mathrm{Me} 2} \mathrm{~N}_{4}(\text { tren })\right)\right]_{2}\left(\mu^{2}-\mathrm{O}\right)\left(\mathrm{PF}_{6}\right)_{2} \cdot 3 \mathrm{MeCN}(\mathbf{3})$. At low temperatures, in protic solvents, an intermediate is detected, the details of which will be the subject of a separate paper. Although the thiolate ligand does not appear to perturb the metrical parameters of the unsupported $\mu$-oxo bridge $\left(\mathrm{Fe}-\mathrm{O}=1.807(8) \AA\right.$, and $\mathrm{Fe}-\mathrm{O}-\mathrm{Fe}=155.3(5)^{\circ}$ fall in the usual range), it decreases the magnetic coupling between the irons $\left(J=-28 \mathrm{~cm}^{-1}\right)$ and creates a rather basic oxo site. Protonation of this oxo using strong $\left(\mathrm{HBF}_{4}, \mathrm{HCl}\right)$ or weak (HOAc, $\mathrm{NH}_{4} \mathrm{PF}_{6}$, LutNHCl) acids results in bridge cleavage to cleanly afford the corresponding monomeric anion-ligated $\left(\mathrm{OAc}^{-}(\mathbf{6})\right.$, or $\left.\mathrm{Cl}^{-}(\mathbf{7})\right)$ or solvent-ligated ( $\left.\mathrm{MeCN}(4)\right)$ derivatives. Addition of $\mathrm{OH}^{-}$converts $\left[\mathrm{Fe}^{\mathrm{III}}\left(\mathrm{S}^{\mathrm{Me} 2} \mathrm{~N}_{4} \text {-(tren))(MeCN)}\right]^{2+}\right.$ (4) back to $\mu$-oxo 3. Thus, $\mu$-oxo bridge cleavage is reversible. The protonated $\mu$-hydroxo-bridged intermediate is not observed. In an attempt to prevent $\mu$-oxo dimer formation, and facilitate the observation of $\mathrm{O}_{2}$-bound intermediates, a bulkier tertiary amine ligand, tren- $\mathrm{Et}_{4}=N$-(2-amino-ethyl)- $N$-(2-diethylaminoethyl)- $N^{\prime}, N^{\prime}$-diethyl-ethane-1,2-diamine, and the corresponding $\left[\mathrm{Fe}^{\mathrm{II}}\left(\mathrm{S}^{\mathrm{Me} 2} \mathrm{~N}_{4}\left(\operatorname{tren}-\mathrm{Et}_{4}\right)\right)\right]^{+}$(5) complex was synthesized and structurally characterized. Steric repulsive interactions create unusually long $\mathrm{Fe}^{\mathrm{II}}-\mathrm{N}(3,4)$ amine bonds in $\mathbf{5}$ (mean distance = 2.219(1) $\AA$ ). The [(tren$\left.\left.\mathrm{Et}_{4}\right) \mathrm{N}_{4} \mathrm{~S}^{\mathrm{Me} 2}\right]^{1-}$ ligand is unable to accommodate iron in the +3 oxidation state, and consequently, in contrast to most thiolate-ligated $\mathrm{Fe}(\mathrm{II})$ complexes, $\left[\mathrm{Fe}^{\mathrm{II}}\left(\mathrm{S}^{\mathrm{Me} 2} \mathrm{~N}_{4}(\text { tren-Et } 4)\right)\right]^{+}(\mathbf{5})$ does not readily react with $\mathrm{O}_{2}$. Oxidation of $\mathbf{5}$ is irreversible, and the potential $\left(E_{\mathrm{p}}{ }^{\mathrm{a}}=+410 \mathrm{mV}\right.$ (vs SCE)) is anodically shifted relative to $\mathbf{1}\left(E_{1 / 2}=-100 \mathrm{mV}\right.$ (vs SCE))

“Corresponding author. kovacs@ @ chem.washington.edu. Phone: (206) 543-0713. Fax: (206) 685-8665.

†UW staff crystallographer.

Supporting Information Available: Crystallographic data for $\mathbf{3}$ and $\mathbf{5}$, electronic absorption spectrum of $\mathbf{3}$ (in $\mathrm{MeCN}$ and $\mathrm{MeOH}$ ), magnetic data ( $1 / \chi$ vs $T$ and $\mu_{\mathrm{eff}}$ vs $T$ ), electronic absorption spectrum showing the intermediate that forms in the low $T$ reaction between 1 and $\mathrm{O}_{2}$, electronic absorption spectrum showing that the $\mu$-oxo bridge of dimeric $\left[\left(\mathrm{Fe}^{\mathrm{III}}\left(\mathrm{S}^{\mathrm{Me} 2} \mathrm{~N}_{4}(\operatorname{tren})\right)_{2}(\mu-\mathrm{O})\right]^{2+}(3)\right.$ is cleaved upon the addition of 2 equiv of $\mathrm{HCl}_{(\mathrm{aq})}, \mathrm{HBF}_{4}$, or LutNHCl, ${ }^{1} \mathrm{H}$ NMR spectrum of $\mathbf{5}$, and electronic absorption spectrum of 5. This material is available free of charge via the Internet at http://pubs.acs.org. 
The bioinorganic chemistry of iron is rich and diverse, ${ }^{1-7}$ catalyzing reactions that range from $\mathrm{O}_{2}$-transport and activation, to hydrogen atom abstraction, alkane functionalization, and substrate hydrolysis. Non-heme iron enzymes are involved in a number of important biosynthetic pathways including DNA synthesis and repair, ${ }^{1,8}$ serotonin,,${ }^{9}$ leukotriene,, $10-12$ plant hormone, ${ }^{13,14}$ and antibiotic synthesis. ${ }^{4} 14$ Cysteinate-ligated non-heme iron enzymes such as nitrile hydratase, ${ }^{6,15}$ superoxide reductase, ${ }^{16-23}$ and peptide deformylase ${ }^{24,25}$ represent a new class of these enzymes. ${ }^{6}$ Superoxide reductases (SORs) ${ }^{16-23}$ are non-heme iron enzymes that contain iron in an environment that is structurally very similar to that of the heme-enzyme cytochrome P450 (Scheme 1). ${ }^{26-29}$ In the catalytically active state, both have four equatorial $\mathrm{sp}^{2}$-nitrogens (histidine ( $\left.\mathrm{SOR}\right)^{16,23}$ or pyrrole (cyt $\mathrm{P} 450$ ) nitrogens), and an apical cysteinate trans to an open coordination site. Both enzymes react with oxygenderived substrates to afford related intermediates. Cytochrome $\mathrm{P} 450$ reacts with dioxygen (plus an electron and proton; $\mathrm{O}_{2}+\mathrm{H}^{+}+\mathrm{e}^{-}=\mathrm{HO}_{2}$ ) to afford an Fe $\mathrm{Fe}^{\mathrm{III}}-\mathrm{OOH}$ intermediate, which undergoes $\mathrm{O}-\mathrm{O}$ bond cleavage to afford a high-valent $\mathrm{Fe}-$ oxo upon the addition of protons. ${ }^{26-31}$ Superoxide reductase $\left(\mathrm{SOR}\right.$ ) reacts with superoxide (plus a proton $=\mathrm{HO}_{2}$ ) to afford an $\mathrm{Fe}{ }^{\mathrm{III}}-\mathrm{OOH}$ intermediate, which undergoes $\mathrm{Fe}-\mathrm{O}$ bond cleavage to afford $\mathrm{H}_{2} \mathrm{O}_{2}$ (Scheme 2a). ${ }^{17-19,21}$ Why the $\mathrm{O}-\mathrm{O}$ bond cleaves with cyt $\mathrm{P} 450,{ }^{26,27}$ whereas the $\mathrm{Fe}-\mathrm{O}$ bond cleaves with SOR is a question worth addressing. Site specific delivery of protons to the proximal as opposed to distal oxygen would be expected to favor $\mathrm{Fe}-\mathrm{O}$ bond cleavage. ${ }^{27}$ However, it is difficult to imagine how site-directed proton delivery would occur with SOR when the metal ion is sitting on the protein surface exposed to solvent. Spin-state differences might contribute to differences in the $\mathrm{O}-\mathrm{O}$ versus $\mathrm{Fe}-\mathrm{O}$ bond cleaving properties, ${ }^{32}$ as well as differences in the ligand environment. The $\mathrm{P} 450 \mathrm{Fe} \mathrm{F}^{\mathrm{III}}-\mathrm{OOH}$ is $S=1 / 2,{ }^{28}$ whereas the SOR Fe ${ }^{\mathrm{III}}-\mathrm{OOH}$ is believed to be $S=5 / 2 \cdot{ }^{17}$ Antibonding electrons present in the high-spin ( $S$ $=5 / 2$ ) structure would weaken the $\mathrm{Fe}-\mathrm{O}$ bond relative to the low-spin structure. A conjugated porphyrin ligand would help to stabilize the high-valent " $\mathrm{Fe}=\mathrm{V}=$ " intermediate that would result from $\mathrm{O}-\mathrm{O}$ bond cleavage. A non-heme environment, although more flexible, ${ }^{33}$ is less capable of supporting a higher-valent " $\mathrm{Fe}^{\mathrm{V}}=\mathrm{O}$ " oxidation catalyst $\mathrm{t}^{34}$ (although it would be capable of supporting an $\mathrm{Fe}^{\mathrm{IV}}=\mathrm{O}$ ). ${ }^{7,35,36}$ The cysteinate present both in the SOR and P450 active sites would also contribute to the stabilization of a high-valent $\mathrm{Fe}=\mathrm{O} .{ }^{37}$ Thiolates have been shown to be quite effective at stabilizing iron in higher oxidation states. ${ }^{6}$ The positioning of the $\mathrm{P} 450$ cysteinate trans to the dioxygen binding site is also believed to play an important role in controlling $\mathrm{O}-\mathrm{O}$ bond cleavage. ${ }^{28,30,38-41}$ However, since the planar architecture of the porphyrin ligand constrains the cysteinate to a trans position relative to incoming dioxygen molecule, it is impossible to determine empirically whether the stereochemical relationship between the $\mathrm{O}_{2}$ and the cysteinate is critical to P450's function.

Recently, we described a functional SOR model, $\left[\mathrm{Fe}^{\mathrm{II}}-\left(\mathrm{S}^{\mathrm{Me} 2} \mathrm{~N}_{4}(\text { tren })\right)\right]^{+}(\mathbf{1}),{ }^{42}$ that reacts with superoxide $\mathrm{O}_{2}{ }^{-}$in $\mathrm{MeOH}$ at $-90{ }^{\circ} \mathrm{C}$ to generate the first example of an $\mathrm{Fe}^{\mathrm{III}}-\mathrm{OOH}$ containing sulfur in the coordination sphere, $\left[\mathrm{Fe}^{\mathrm{III}}-\left(\mathrm{S}^{\mathrm{Me} 2} \mathrm{~N}_{4}(\text { tren })\right)(\mathrm{OOH})\right]^{+}(\mathbf{2}$; Scheme 2b). ${ }^{43}$ Although the thiolate is coordinated cis to the open coordination site in $\mathbf{1}$, as opposed to trans, as it is with the SOR enzyme, ${ }^{17,19,21,22,44}$ this appears to have little effect on its superoxide reduction chemistry. Intermediate 2 is low-spin $(S=1 / 2)$, displays a $v_{\mathrm{O}-\mathrm{O}}$ at 784 $\mathrm{cm}^{-1}$ (that shifts to $753 \mathrm{~cm}^{-1}$ upon isotopic labeling with ${ }^{18} \mathrm{O}_{2}^{-}$), a $\rightarrow \mathrm{Fe}^{\mathrm{III}}$ charge-transfer 
band at 452-(2900) nm, ${ }^{45}$ and a coordinated diatomic oxygen ligand (with one short, and one long $\mathrm{Fe}-\mathrm{O}$ distance at 1.86(3) $\AA$, and 2.78(3) $\mathrm{A}$, respectively, as determined by EXAFS). ${ }^{43}$ Herein, we examine the reactivity between our thiolate-ligated five-coordinate complex $\left[\mathrm{Fe}^{\mathrm{II}}\left(\mathrm{S}^{\mathrm{Me} 2} \mathrm{~N}_{4}(\text { tren })\right)\right]^{+}(\mathbf{1})$ and dioxygen, in order to determine if $\mathrm{O}_{2}$ activation can be promoted when $\mathrm{O}_{2}$ binds cis to a thiolate. Also described are our attempts at trapping out intermediates in this reaction by incorporating bulky tertiary amines in place of primary amines. Reactions between $\mathbf{1}$ and dioxygen or superoxide are dramatically altered by a simple modification of our ligand system.

\section{Experimental Section}

\section{General Methods}

All reactions were performed under an atmosphere of dinitrogen in a glovebox or by using standard Schlenk techniques, or by using a custom-made solution cell equipped with a threaded glass connector sized to fit a dip probe. Reagents purchased from commercial vendors were of the highest purity available and used without further purification.

Tetrahydrofuran (THF), $\mathrm{Et}_{2} \mathrm{O}$, and $\mathrm{MeCN}$ were rigorously degassed and purified using solvent purification columns housed in a custom stainless steel cabinet, dispensed via a stainless steel Schlenk-line (Glass-Contour). Methanol (MeOH) was distilled from magnesium methoxide. ${ }^{1} \mathrm{H}$ NMR spectra were recorded on a Bruker AF 300 and Bruker DPX 200 FT-NMR spectrometers and are referenced to an external standard of TMS (paramagnetic compounds) or to residual protio-solvent (diamagnetic compounds). Chemical shifts are reported in ppm, and coupling constants $(J)$ are in Hz. IR spectra were recorded on a Perkin-Elmer 1700 FT-IR spectrometer as $\mathrm{KBr}$ pellets. Cyclic voltammograms were recorded in $\mathrm{MeCN}\left(100 \mathrm{mM} \mathrm{Bu}^{\mathrm{n}}{ }_{4} \mathrm{~N}\left(\mathrm{PF}_{6}\right)\right.$ solutions) on a PAR 273 potentiostat utilizing a glassy carbon working electrode, a platinum auxiliary electrode, and an SCE reference electrode. Magnetic moments (solution state) were obtained using the Evans method as modified for superconducting solenoids. ${ }^{46,47}$ Temperatures were obtained using Van Geet's method. ${ }^{48}$ Solid-state magnetic measurements were obtained with polycrystalline samples in gel caps using a Quantum Design MPMS S5 SQUID magnetometer. Ambient temperature electronic absorption spectra were recorded on a Hewlett-Packard model 8450 spectrometer, interfaced to an IBM PC. Low-temperature electronic absorption spectra were recorded using a Varian Cary 50 spectro-photometer equipped with a fiber optic cable connected to a "dip" ATR probe (C-technologies), with a custom-built two-neck solution sample holder equipped with a threaded glass connector (sized to fit the dip probe). Thiolate-ligated $\left[\mathrm{Fe}^{\mathrm{II}}\left(\mathrm{S}^{\mathrm{Me} 2} \mathrm{~N}_{4}(\right.\right.$ tren $\left.\left.)\right)\right]\left(\mathrm{PF}_{6}\right)(\mathbf{1})$ and $\left[\mathrm{Fe}^{\mathrm{III}}\left(\mathrm{S}^{\mathrm{Me} 2} \mathrm{~N}_{4}(\text { tren })\right)(\mathrm{MeCN})\right]^{2+}(\mathbf{4})$ were synthesized as previously described. ${ }^{42,43}$

\section{Preparation of $\left[\mathrm{Fe}^{\mathrm{III}}\left(\mathrm{S}^{\mathrm{Me} 2} \mathrm{~N}_{4}(\operatorname{tren})\right)\right]_{2}(\mu-0)\left(\mathrm{PF}_{6}\right) 2 \cdot \mathrm{MeCN}(3)$}

A solution of $2.00 \mathrm{mmol}$ of $\left[\mathrm{Fe}^{\mathrm{II}}\left(\mathrm{S}^{\mathrm{Me} 2} \mathrm{~N}_{4}(\operatorname{tren})\right)\right]\left(\mathrm{PF}_{6}\right)(\mathbf{1}, 864 \mathrm{mg})$ in $30 \mathrm{~mL}$ of methanol was stirred in air for $30 \mathrm{~min}$, and then stirred under $\mathrm{N}_{2}$ for an additional $4 \mathrm{~h}$. The volatiles were then removed, and the resulting brick red powder was dissolved in $10 \mathrm{~mL}$ of $\mathrm{MeCN}$, filtered through a piece of glass wool, and layered with $50 \mathrm{~mL}$ of $\mathrm{Et}_{2} \mathrm{O}$. The two layers diffused together over several days affording brick red crystals of $\mathbf{3}$ (863 mg, 98.1\%). Electronic absorption $\lambda_{\max }, \mathrm{nm}\left(\varepsilon, \mathrm{cm}^{-1} \mathrm{M}^{-1}\right)$ : 243 (sh); 289(9350); 331(8825); 483(5290). 
IR ( $\mathrm{KBr}$ pellet): $v_{\mathrm{C}=\mathrm{N}} 1649 \mathrm{~cm}^{-1} ; v_{\mathrm{C}=\mathrm{N}} 1594 \mathrm{~cm}^{-1}$. Magnetic moment (solid state, $300 \mathrm{~K}$ ): $2.5 \mu_{\mathrm{B}} / \mathrm{Fe}$. Anal. for $\mathrm{Fe}_{2} \mathrm{C}_{21} \mathrm{H}_{46} \mathrm{~N}_{8} \mathrm{~S}_{2} \mathrm{OP}_{2} \mathrm{~F}_{12}$ Calcd: $\mathrm{C}, 29.09 ; \mathrm{H}, 5.55 ; \mathrm{N}, 12.33$. Found: $\mathrm{C}$, 29.68; H, 5.25; N, 11.72 .

\section{Alternative Preparation of $\left[\mathrm{Fe}^{\mathrm{III}}\left(\mathrm{S}^{\mathrm{Me} 2} \mathrm{~N}_{4}(\text { tren })\right)_{2}(\mu-0)\left(\mathrm{BPh}_{4}\right)_{2}-\left(3-\mathrm{BPh}_{4}\right)\right.$}

Tetrabutylammonium hydroxide ( $14 \mu \mathrm{L}, 0.097 \mathrm{mmol})$ was added to a MeCN solution of $\left[\mathrm{Fe}^{\mathrm{III}}\left(\mathrm{S}^{\mathrm{Me} 2} \mathrm{~N}_{4}(\right.\right.$ tren $\left.\left.)\right)(\mathrm{MeCN})\right]-\left(\mathrm{BPh}_{4}\right)_{2}(4,50 \mathrm{mg}, 0.051 \mathrm{mmol})$ at ambient temperature, and then stirred under $\mathrm{N}_{2}$ for $4 \mathrm{~h}$. The volatiles were then removed, and the resulting brick red powder was dissolved in $\mathrm{MeOH}$, filtered over Celite, and layered with $25 \mathrm{~mL}_{\text {of }} \mathrm{Et}_{2} \mathrm{O}$. A red solid was isolated affording $\mathbf{3}(17 \mathrm{mg}, 53 \%)$.

\section{Preparation of [Bis-(2-diethylamino-ethyl)-amino]-acetonitrile (Bean)}

An aqueous solution $(20 \mathrm{~mL})$ of $N, N, N^{\prime}, N^{\prime}$-tetraethyldi-ethylenetriamine $(10.77 \mathrm{~g}, 50 \mathrm{mmol})$ was cooled to $0{ }^{\circ} \mathrm{C}$, and $\mathrm{HCl}(32 \%$ aq solution, $5.70 \mathrm{~g}, 50 \mathrm{mmol})$ was added in one portion. The solution was then cooled to $-10{ }^{\circ} \mathrm{C}$, and an aqueous solution $(30 \mathrm{~mL})$ of $\mathrm{KCN}(3.26 \mathrm{~g}$, $50 \mathrm{mmol}$ ) was added slowly. To this was added an aqueous formaldehyde solution (37\%, $4.06 \mathrm{~g}, 50 \mathrm{mmol}$ ) at such a rate that the solution temperature did not exceed $0{ }^{\circ} \mathrm{C}$. This was then brought to room temperature and stirred overnight. Methylene chloride $(100 \mathrm{~mL})$ was then added, and the organic layer was extracted and washed with water two times $(10 \mathrm{~mL}$ each time), which was followed by brine twice (10 mL each time). The organic layer was then dried with $\mathrm{MgSO}_{4}$ and the solvent removed by rotary evaporation yielding a pale yellow oil (10.25 g, 80.9\%). $300 \mathrm{MHz}{ }^{1} \mathrm{H}$ NMR $\left(\mathrm{CDCl}_{3}\right)$ : 3.74 (s, $\left.2 \mathrm{H}, \mathrm{CH}_{2} \mathrm{CN}\right), 2.61-2.41$ $\left(\mathrm{m}, 16 \mathrm{H}, \mathrm{CH}_{2}\right), 0.96\left(\mathrm{t}, 12 \mathrm{H}, \mathrm{J}=7 \mathrm{~Hz}, \mathrm{CH}_{3}\right) .50 \mathrm{MHz}{ }^{13} \mathrm{C} \mathrm{NMR}\left(\mathrm{CDCl}_{3}\right): 115.9(\mathrm{C} \equiv \mathrm{N})$, $52.7\left(\mathrm{CH}_{2}\right), 51.4\left(\mathrm{CH}_{2}\right), 47.5\left(\mathrm{CH}_{2}\right), 43.1\left(\mathrm{CH}_{2}\right), 11.9\left(\mathrm{CH}_{3}\right)$. HR-MS (FAB) Calcd: 255.2549. Found: 255.2548 .

\section{Preparation of $N$-(2-Amino-ethyl)- $N$-(2-diethylamino-ethyl)- $N^{\prime}, N^{\prime}$-diethyl-ethane-1,2-diamine (Tren-Et $\left.{ }_{4}\right)$}

Lithium aluminum hydride $(4.55 \mathrm{~g}, 120 \mathrm{mmol})$ was suspended in THF $(100 \mathrm{~mL})$ and cooled to $-15{ }^{\circ} \mathrm{C}$. To this suspension, was added $\mathrm{H}_{2} \mathrm{SO}_{4}(96 \%$ aq, $6.13 \mathrm{~g}, 60 \mathrm{mmol})$ dropwise over the period of $30 \mathrm{~min}$. The reaction mixture was then brought to $0{ }^{\circ} \mathrm{C}$ and stirred for an additional hour. To this, bean $(8.56 \mathrm{~g}, 33.8 \mathrm{mmol})$ was added dropwise via syringe at a rate such that the solution did not rise above $20^{\circ} \mathrm{C}$. The reaction was then brought to room temperature and stirred overnight. The remaining $\mathrm{AlH}_{3}$ was then quenched with a large excess of $\mathrm{H}_{2} \mathrm{O}$ and filtered. The residue was washed with a large volume of methylene chloride and the organic layer extracted. This layer was then dried with $\mathrm{MgSO}_{4}$ and the solvent removed by rotary evaporation yielding tren-Et 4 as a musky smelling yellow oil that was spectroscopically pure $(7.04 \mathrm{~g}, 81.0 \%) .300 \mathrm{MHz}{ }^{1} \mathrm{H} \mathrm{NMR}\left(\mathrm{CDCl}_{3}\right): 2.76-2.48(\mathrm{~m}$, 20H, $\mathrm{CH}_{2}$ ), 2.34 (bs, $2 \mathrm{H}, \mathrm{NH}_{2}$ ), 1.07 (t, $12 \mathrm{H}, \mathrm{J}=6 \mathrm{~Hz}, \mathrm{CH}_{3}$ ). $50 \mathrm{MHz}^{13} \mathrm{C}$ NMR: 57.2 $\left(\mathrm{CH}_{2}\right), 52.5\left(\mathrm{CH}_{2}\right), 50.9\left(\mathrm{CH}_{2}\right), 46.8\left(\mathrm{CH}_{2}\right), 39.3\left(\mathrm{CH}_{2}\right), 11.1\left(\mathrm{CH}_{3}\right)$. HR-MS (FAB) Calcd: 259.2862. Found: 259.2862. 


\section{Preparation of $\left[\mathrm{Fe}^{\mathrm{II}}\left(\mathrm{S}^{\mathrm{Me} 2} \mathrm{~N}_{4}\left(\right.\right.\right.$ tren- $\left.\left.\left.-\mathrm{Et}_{4}\right)\right)\right]\left(\mathrm{PF}_{6}\right)(5)$}

Sodium hydroxide ( $80 \mathrm{mg}, 2.00 \mathrm{mmol}$ ) was dissolved in $10 \mathrm{~mL}$ of $\mathrm{MeOH}$ followed by the addition of 3-methyl-3-mercapto-2-butanone (236 mg, $2.00 \mathrm{mmol}) .{ }^{10} \mathrm{Tren}^{-E_{4}}(514 \mathrm{mg}$, $2.00 \mathrm{mmol}$ ) was then added to the thiolate solution and the reaction mixture cooled to -20 ${ }^{\circ} \mathrm{C}$. A cold $\left(-20{ }^{\circ} \mathrm{C}\right)$ solution of $\mathrm{FeCl}_{2}(252 \mathrm{mg}, 2.00 \mathrm{mmol}$ in $5 \mathrm{~mL}$ of $\mathrm{MeOH})$ was then added to the ligand solution dropwise, producing a yellow solution, which progressed to a dark brown solution over $1 \mathrm{~h}$. After $24 \mathrm{~h}, \mathrm{NaPF}_{6}(334 \mathrm{mg}, 2.00 \mathrm{mmol}$ ) was added, and the reaction stirred another hour. The reaction mixture was then filtered, and all volatiles were removed by vacuum at room temperature affording a brown tar. This was dissolved in $\mathrm{MeCN}$, filtered through a bed of Celite, and concentrated to $\sim 5 \mathrm{~mL}$. The solution was then layered with $\mathrm{Et}_{2} \mathrm{O}(20 \mathrm{~mL})$, and the two layers were allowed to diffuse together over several days. The pale green filtrate was then separated from the resulting white and black solids. Green crystals of $\mathbf{5}$ were obtained in low yields by slow evaporation of solvent over several days (161 mg, 13\%). $200 \mathrm{MHz}{ }^{1} \mathrm{H} \mathrm{NMR}\left(\mathrm{MeCN}-d_{3}\right): 43.9$ (bs), 7.46 (s), 5.46 (s), 3.67 (s), 3.47 (s), 1.99 (s), 1.73(s), -4.68 (bs), -16.46 (bs). Electronic absorption $\lambda_{\max } \mathrm{nm}\left(\varepsilon \mathrm{cm}^{-1}\right.$ $\mathrm{M}^{-1}$ ): 223 (7900), 314 (745), 330 (790), 369 (370). IR (KBr pellet): $v_{\mathrm{C}=\mathrm{N}} 1633 \mathrm{~cm}^{-1}$. Magnetic moment (MeCN solution, $302 \mathrm{~K}$ ): $4.96 \mu_{\mathrm{B}}$. Anal. for $\mathrm{FeC}_{19} \mathrm{H}_{41} \mathrm{~N}_{4} \mathrm{SPF}_{6}$ Calcd: $\mathrm{C}$, 40.87; H, 7.40; N, 10.03. Found: C, 41.07; H, 7.48; N, 10.22.

\section{$\mu$-Oxo Bridge Cleaving Reactions}

Acids (2 equiv, in 0.125 equiv aliquots) were injected via syringe into a cold $\left(-20^{\circ} \mathrm{C}\right)$ MeCN solution containing $\left[\mathrm{Fe}^{\mathrm{III}}\left(\mathrm{S}^{\mathrm{Me} 2} \mathrm{~N}_{4}(\text { tren })\right)_{2} \mu-\mathrm{O}\left(\mathrm{PF}_{6}\right)_{2} \bullet \mathrm{MeCN}(3)\right.$ in a custom-made two-neck vial equipped with a septum cap, and threaded dip-probe feed-through adaptor. Reactions were monitored by electronic absorption spectroscopy, and spectra were recorded after the addition of each 0.125 equiv aliquot.

\section{X-ray Crystallographic Structure Determination}

A dark red crystal of $\mathbf{3}$ was cut to $0.41 \times 0.24 \times 0.05 \mathrm{~mm}^{3}$, submerged in mineral oil, placed on a glass capillary, and mounted over a stream of cold nitrogen gas $\left(-130(2){ }^{\circ} \mathrm{C}\right)$. The crystal-to-detector distance was set to $30 \mathrm{~mm}$, and exposure time was $50 \mathrm{~s} \mathrm{deg}^{-1}$ for all data sets with a scan width of $1^{\circ}$. The data collection was $72.6 \%$ complete to $26.37^{\circ}$ in $\mathcal{M}$. A total of 77312 partial and complete reflections were collected covering the indices $h=-11$ to $11, k=-21$ to $20, l=-45$ to 45 . Of these, 12010 reflections were symmetry independent, and the $R_{\text {int }}=0.1519$ indicated that the data was fair. Indexing and unit cell refinements indicated a monoclinic $P$ lattice in the space group $P 2_{1} / c$. Pale green crystals of 5 were submerged in mineral oil. A suitable single crystal $\left(0.43 \times 0.29 \times 0.22 \mathrm{~mm}^{3}\right)$ was selected, placed on a glass capillary, and mounted over a stream of cold nitrogen gas $\left(-130(2){ }^{\circ} \mathrm{C}\right)$. The crystal-to-detector distance was set to $30 \mathrm{~mm}$, and exposure time was $10 \mathrm{~s} \mathrm{deg}^{-1}$ for all data sets with a scan width of $2^{\circ}$. The data collection was $96.3 \%$ complete to $28.28^{\circ}$ in $\mathcal{M}$. A total of 20333 partial and complete reflections were collected covering the indices, $h=-11$ to $10, k=-13$ to 14 , and $l=-18$ to 18 . Of the reflections, 5300 were symmetry-independent, and the $R_{\text {int }}=0.045$ indicated the data quality was excellent. Indexing and unit cell refinements indicated a monoclinic $P$ lattice in the space group $P c$. 
The data for both $\mathbf{3}$ and $\mathbf{5}$ were integrated and scaled using Denzo-hkl-SCALEPACK, and an absorption correction was performed using SORTAV. Solution by direct methods produced a complete heavy atom phasing model. All non-hydrogen atoms were refined anisotropically by full-matrix least-squares methods, while all hydrogen atoms were then placed using a riding model. Crystal data for $\mathbf{3}$ and $\mathbf{5}$ are presented in Table 1. Selected bond distances and angles are contained in Table 2.

\section{Results and Discussion}

\section{Reaction of [Fe" $\left(\mathrm{S}^{\mathrm{Me} 2} \mathrm{~N}_{\mathbf{4}}(\right.$ tren $\left.\left.)\right)\right]\left(\mathrm{PF}_{6}\right)$ with Dioxygen}

Previously, ${ }^{42,43}$ we showed that superoxide $\left(\mathrm{O}_{2}{ }^{-}\right)$reacts with the five-coordinate ferrous complex $\left[\mathrm{Fe}^{\mathrm{II}}\left(\mathrm{S}^{\mathrm{Me} 2} \mathrm{~N}_{4}(\right.\right.$ tren) $\left.)\right]\left(\mathrm{PF}_{6}\right)$ (1) (Scheme $2 \mathrm{~b}$ ) via an inner-sphere mechanism to afford a transient hydroperoxide intermediate $\mathbf{2}$. A ferrous superoxide-ligated intermediate is not detected in this reaction. Hydrogen peroxide (detected by mass spectrometry, ${ }^{1} \mathrm{H}$ NMR, and IR) is released from intermediate 2 upon protonation ${ }^{49}$ to afford the six-coordinate, solvent-ligated ferric complexes $\left[\mathrm{Fe}^{\mathrm{III}}-\left(\mathrm{S}^{\mathrm{Me} 2} \mathrm{~N}_{4}(\text { tren })\right)(\text { solv })\right]^{2+}($ solv $=\mathrm{MeCN}(4)$ or $\mathrm{MeOH})^{42,43}$ Addition of dioxygen to complex 1, on the other hand, affords a different product at ambient temperature. Complete formation of this product requires 0.25 equiv of $\mathrm{O}_{2}$ per iron (as measured by $\mathrm{O}_{2}$ consumption using a known-volume bulb). This stoichiometry is consistent with the formation of a $\mu$-oxo dimer, as was confirmed by $\mathrm{X}$-ray crystallography.

$\mathrm{X}$-ray quality crystals of the final product formed in the reaction between $\mathbf{1}$ and dioxygen $\left.\left[\mathrm{Fe}^{\mathrm{III}}\left(\mathrm{S}^{\mathrm{Me} 2} \mathrm{~N}_{4}(\text { tren })\right)\right]_{2}\left(\mu^{2}-\mathrm{O}\right)\right]\left(\mathrm{PF}_{6}\right)_{2} \cdot 3 \mathrm{MeCN}(\mathbf{3}$, Figure 1) were produced via slow diffusion of $\mathrm{Et}_{2} \mathrm{O}$ into a MeCN solution. This complex crystallized in the $P 2_{1} / c$ space group, with two structurally distinct binuclear iron complexes per asymmetric unit. Metrical parameters for the two dimers differ only slightly (see Supporting Information). Binuclear $\left[\mathrm{Fe}^{\mathrm{III}}\left(\mathrm{S}^{\mathrm{Me} 2} \mathrm{~N}_{4}(\right.\right.$ tren $\left.\left.)\right)\right] 2-\left(\mu^{2}-\mathrm{O}\right)^{2+}$ is dicationic and contains an unsupported $\mu$-oxo bridge that connects two pseudo-octahedrally coordinating $\mathrm{Fe}^{\mathrm{III}}$ ions. As shown in the ORTEP diagram of Figure 1, the two halves of the dimer are twisted $\left(\sim 90^{\circ}\right)$ relative to one another, presumably in order to relieve steric repulsive interactions between the gem dimethyls adjacent to the thiolate sulfurs. ${ }^{50}$ The bridging oxo-ligand is trans to the imine-nitrogens and

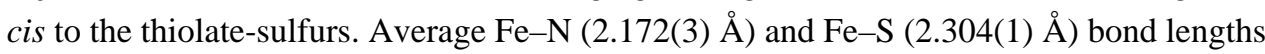
in $\mathbf{3}$ are longer than low-spin complexes containing $\mathrm{Fe}^{\mathrm{III}}$ in this ligand environment (Table 2). This is, in part, because the irons are either high-spin $(S=5 / 2)$ or intermediate-spin ( $S$ $=3 / 2$ ) (vide infra), ${ }^{6-8}$ and in part due to the trans effect of the oxo and thiolate ligands. The bridging oxo ligand is at an average distance of 1.807(4) $\AA$ from the iron centers, with an average $\mathrm{Fe}-\mathrm{O}-\mathrm{Fe}$ bond angle of $152.51(8)^{\circ}$. These metrical parameters are typical of $\mu$-oxo dimers $^{50-54}$ and reflect extensive $\pi$-bonding within the $\mathrm{Fe}-\mathrm{O}-\mathrm{Fe}$ core. ${ }^{9}$ Diferric $\mu$-oxo bridges are quite flexible, support $\mathrm{Fe}-\mathrm{O}-\mathrm{Fe}$ angles ranging from $114^{\circ}$ to $180^{\circ}$, and typically possess unusually short $\mathrm{Fe}-\mathrm{O}$ distances.$^{51}$ Unsupported $\mu$-oxo-bridged structures tend to have $\mathrm{Fe}-\mathrm{O}-\mathrm{Fe}$ angles closer to linear: the smallest $\mathrm{Fe}-\mathrm{O}-\mathrm{Fe}$ angle in an unsupported bridge structure is $139^{\circ} .{ }^{51}$ Thiolate-ligated $\mu$-oxo dimers are extremely rare. ${ }^{52,55}$ This is because $\mathrm{O}_{2}$ oxidation reactions typically afford disulfides, metallosulfoxides $(\mathrm{M}-\mathrm{S}(=\mathrm{O}) \mathrm{R})$, or metallosulfones $\left(\mathrm{M}-\mathrm{SO}_{2} \mathrm{R}\right)$, when thiolates are in the coordination sphere. ${ }^{56}$ The only other 
two examples of thiolate-ligated binuclear $\mu$-oxo-bridged iron complexes are [(bmedaco)Fe $\left.{ }^{\mathrm{III}}\right]_{2}(\mu-\mathrm{O})$ reported by Darensbourg ${ }^{52}$ and $[(\mathrm{bmmp}-\mathrm{TASN}) \mathrm{Fe}]_{2}(\mu-\mathrm{O})$ reported by Grapperhaus. ${ }^{55} \mathrm{In}$ all three of these examples, the thiolate sulfur does not appear to perturb the strong $\mathrm{Fe}-\mathrm{O}$ (oxo) bonds: $\mathrm{Fe}-\mathrm{O}$ bond lengths in these complexes fall in the usual range. Bond lengths and angles for $\mu$-oxo-bridged $\mathbf{3}$ are compared with those of its reduced $\mathrm{Fe}$ (II) precursor 1, as well as oxidized $\left[\mathrm{Fe}^{\mathrm{III}}\left(\mathrm{S}^{\mathrm{Me} 2} \mathrm{~N}_{4}(\text { tren })\right)(\mathrm{MeCN})\right]^{2+}(\mathbf{4})$, in Table 2.

\section{Mechanism of $\mu$-Oxo 3 Formation via Reaction of 1 with $\mathrm{O}_{2}$}

The generally accepted mechanism for $\mathrm{O}_{2}$-induced $\mu$-oxo dimer formation (in aprotic solvents) comes from the well-developed iron porphyrin literature ${ }^{57,58}$ and is believed to involve initial coordination of $\mathrm{O}_{2}$ to $\mathrm{Fe}^{\mathrm{II}}$ to afford an $\mathrm{Fe}^{\mathrm{III}}-\mathrm{O}_{2}{ }^{-}$(superoxide) intermediate. Reaction of this $\mathrm{Fe}^{\mathrm{III}}-\mathrm{O}_{2}$-intermediate with 1 equiv of $\mathrm{Fe}^{\mathrm{II}}$ starting material would afford a peroxide-bridged $\mathrm{Fe}_{2}{ }^{\mathrm{III}}\left(\mu-\mathrm{O}_{2}{ }^{2-}\right)$ ferric dimer, that could cleave to afford 2 equiv of an $\mathrm{Fe}(\mathrm{IV})=\mathrm{O}$ (oxo). Reaction of the highly reactive $\mathrm{Fe}(\mathrm{IV})=\mathrm{O}$ with 1 equiv of $\mathrm{Fe}^{\mathrm{II}}$ starting material would afford the thermodynamically stable $\mu$-oxo-bridged binuclear product. In protic solvents, the mechanism is likely to involve protonation of peroxide and/ or superoxide intermediates, rather than peroxide-dimer formation. The inner-sphere mechanism for $\mathrm{O}_{2}{ }^{-}$reduction by our SOR model complex ${ }^{42,43} 1$ suggests that $\mathrm{O}_{2}$ reduction could occur via the initial coordination of $\mathrm{O}_{2}$ to the metal. The site to which $\mathrm{O}_{2}\left(\mathrm{or}_{2}{ }^{-}\right)$ binds ( $c i s$ with respect to the thiolate sulfur) has been established by structurally characterizing more stable analogues, including an $\mathrm{Fe}-\mathrm{NO},{ }^{59}$ and an $\mathrm{Fe}-\mathrm{OAc}$ derivative ${ }^{60}$ If the reaction between $\mathbf{1}$ and $\mathrm{O}_{2}$ is monitored spectrophotometrically at low temperatures, in aprotic solvents such as $\mathrm{MeCN}$ (at $-20^{\circ} \mathrm{C}$ ) and THF (at $-78^{\circ} \mathrm{C}$ ), no intermediates are observed. Instead, 1 rapidly (within seconds) converts directly to $\mathbf{3}$, even at these lower temperatures. In protic solvents such as $\mathrm{MeOH}$, on the other hand, a transient intermediate is observed (by electronic absorption spectroscopy (Figure S-3), and resonance Raman) ${ }^{45}$ when $\mathrm{O}_{2}$ is added to $\mathbf{1}$ at $-78{ }^{\circ} \mathrm{C}$. This supports the possibility that $\mu$-oxo dimer formation from 1 involves an inner-sphere mechanism. Further characterization of this intermediate, as well as the kinetics of its formation, is ongoing.

\section{Electronic, Magnetic, and Redox Properties $\mu$-Oxo-Bridged 3}

Solutions of $\mu$-oxo-bridged 3 are brick-red in $\mathrm{MeOH}, \mathrm{MeCN}$, THF, pyridine, and DMF. In $\mathrm{MeCN}$, the electronic absorption spectrum of $\mathbf{3}$ (Figure S-1) is dominated by an intense charge-transfer band in the visible region, at 483(5290) nm, which is presumably $\mathrm{S} \rightarrow \mathrm{Fe}^{\mathrm{III}}$ in nature. This band shifts to 500(5500) $\mathrm{nm}$ in $\mathrm{MeOH}$ (Figure S-2). Binuclear 3 is irreversibly reduced at a potential of $-1.08 \mathrm{~V}$ versus SCE (in $\mathrm{MeCN}$ ), indicating that $\mathrm{Fe}^{3+}$ ion is highly stabilized by this ligand environment. The irreversibility of this wave suggests that reduction induces cleavage of the $\mu$-oxo bridge. The magnetic properties of $\mathbf{3}$ indicate that the coupling between the $\mathrm{Fe}^{3+}$ ions is weak. The ambient temperature $\mathrm{MeCN}$ solution $\left.\mu_{\text {eff }}\right) 2.5 \mu_{\mathrm{B}}$ per iron. A negative $x$-intercept in the $1 / \chi$ versus temperature (SQUID) plot (Figure S-7) indicates that the two metals are antiferromagnetically coupled in the solid state. Linear fits to the $1 / \chi$ versus $T$ data over the temperature range $55-350 \mathrm{~K}$ give a $\mu_{\text {eff }}=$ $2.5 \mu_{\mathrm{B}}$ per iron (Figure S-8), and a coupling constant of $J=-28 \mathrm{~cm}^{-1}$. This $J$-value falls below the usual range for $\mu$-oxo dimers containing an unsupported bridge.$^{51}$ However, the 
reported range $\left(-65 \mathrm{~cm}^{-1}>J>-195 \mathrm{~cm}^{-1}\right)$ includes only N-,O-ligated $\mathrm{Fe}(\mathrm{III}) \mu$-oxo systems, ${ }^{51}$ suggesting that thiolate-sulfurs weaken this coupling. The increased lability of the $\mu$-oxo bridge (vide infra) in thiolate-ligated $\mathbf{3}$ would be consistent with weaker coupling.

\section{Reactivity of $\mu$-Oxo-Bridged 3}

Although $\mu$-oxo dimers tend to be quite stable (representing the "thermodynamic pit" of $\mathrm{Fe}^{\mathrm{III}}$ chemistry) and unreactive, ${ }^{51}$ there are a few rare reported examples of reactivity. ${ }^{53,61-63}$ Reversible $\mu$-oxo bridge cleavage is seen upon the addition of a proton source $\left(\mathrm{H}_{2} \mathrm{Im}^{+} \mathrm{Cl}^{-}\right)$to [(TPP)Fe $]_{2}(\mu-\mathrm{O})$ in aprotic solvents to afford 2 equiv of [(TPP) $\left.\mathrm{Fe}(\mathrm{HIm})_{2}\right]\left(+\mathrm{H}_{2} \mathrm{O}\right) .{ }^{61}$ Reed has shown that equilibria involving $\mu$-oxo [(TPP)Fe $]_{2}(\mu$ O) to [(TPP) $\left.\mathrm{Fe}-\left(\mathrm{H}_{2} \mathrm{O}\right)\right]^{+}$interconversion will favor the bridge-cleaved aquo complex in rigorously dried aprotic solvents when acidic anions are present. ${ }^{62}$ Protonation of $[(\mathrm{TPP}) \mathrm{Fe}]_{2}(\mu-\mathrm{O})$ using $[\mathrm{H}($ mesitylene $)]\left[\mathrm{B}\left(\mathrm{C}_{6} \mathrm{~F}_{5}\right)_{4}\right]$ affords the protonated monohy-droxybridged porphyrin $[(\mathrm{TPP}) \mathrm{Fe}]_{2}(\mu-\mathrm{OH})^{+} .62$ The unsupported $\mu$-oxo bridge of $\left[(\mathrm{N} 4 \mathrm{Py})_{2} \mathrm{Fe}_{2}(\mu\right.$ $\mathrm{O})]^{+4}\left(\mathrm{~J}=-104 \mathrm{~cm}^{-1}\right)$ is quite labile, and bridge cleavage occurs readily upon the addition of $\mathrm{H}_{2} \mathrm{O}$ or MeOH. ${ }^{53}$ This is despite the presence of rather short Fe-O bonds (1.803(1) $\AA$ ) and is attributed to the relief of steric repulsive interactions between the two halves of the $\left[(\mathrm{N} 4 \mathrm{Py})_{2} \mathrm{Fe}_{2}(\mu-\mathrm{O})\right]^{+4}$ dimer. It is likely that the large cationic charge of $\left[(\mathrm{N} 4 \mathrm{Py})_{2} \mathrm{Fe}_{2}(\mu-\right.$ $\mathrm{O})]^{+4}$ also contributes to its facile bridge cleavage. ${ }^{64}$ Octacationic 5,10,15,20-tetrakis(2,4,6trimethyl-3,5-bis $\{a-N, N, N$-trimethylammoniummethyl $\}$ phenyl)porphinatoiron(III) is resistant to $\mu$-oxo dimer formation, even in water. This is both due to the ligand's steric bulk and extensive charge build-up. ${ }^{64}$ Oxidation of $\mu$-oxo dimers with $\mathrm{H}_{2} \mathrm{O}_{2}$ can lead to highvalent, doubly bridged $\mathrm{Fe}_{2}{ }^{\mathrm{IV}}(\mu-\mathrm{O})_{2}$ diamond cores, via the insertion of an oxygen atom into the singly bridged $\mathrm{Fe}_{2}{ }_{2} \mathrm{III}(\mu-\mathrm{O})$ core. ${ }^{63}$

\section{Reversible $\mu$-Oxo Bridge Cleavage and Formation}

The $\mu$-oxo bridge of $\mathbf{3}$ can be reversibly cleaved with acids (HX) to afford either the corresponding anion-bound ( $\mathrm{Fe}-\mathrm{X})$, or solvent-bound $(\mathrm{Fe}-\mathrm{MeCN})$ products, depending on the acids $\left(\mathrm{NH}_{4}{ }^{+}, \mathrm{HOAc}, \mathrm{HCl}, \mathrm{LutNH}^{+}, \mathrm{HBF}_{4}\right)$ used (Scheme 3; Figure 2 and Figure 3). Addition of hydroxide converts these products back to $\mu$-oxo-bridged 3 (Figure 4 ). For example, addition of 2 equiv of $\mathrm{HOAc}(\mathrm{aq})$ to dimeric 3 at $-20{ }^{\circ} \mathrm{C}$ in MeCN cleanly affords (as demonstrated by the sharp isosbestic point at $520 \mathrm{~nm}$ ) monomeric acetate-ligated [ $\mathrm{Fe}^{\mathrm{III}}$ $\left(\mathrm{S}^{\mathrm{Me} 2} \mathrm{~N}_{4}(\right.$ tren $\left.\left.)\right)(\mathrm{OAc})\right]^{+}(\mathbf{6}){ }^{60}$ This is illustrated in the electronic absorption spectrum of

Figure 2. The final product in this reaction was identified by spectral comparison with authentic samples of 6 (prepared as described elsewhere). ${ }^{60}$ The reaction is complete upon the addition of 2 equiv of HOAc/dimer. When $\mathrm{HCl}(\mathrm{aq})$ is used in place of acetic acid, clean conversion to $\left[\mathrm{Fe}^{\mathrm{III}}\left(\mathrm{S}^{\mathrm{Me} 2} \mathrm{~N}_{4}(\text { tren })\right) \mathrm{Cl}\right]^{+}(7)$ is observed as demonstrated by the sharp isosbestic point at $520 \mathrm{~nm}$ (Figure S-4 of Supporting Information), and comparison with authentic samples of $\mathbf{7}$ (prepared as described elsewhere) ${ }^{59}$ Again, the reaction is complete upon the addition of 2 equiv of $\mathrm{HCl}$ at ambient temperature. These reactions occur despite the presence of water in $\mathrm{HOAc}(\mathrm{aq})$ and $\mathrm{HCl}(\mathrm{aq})$, suggesting that the $\mu$-oxo bridge of $\mathbf{3}$ is more basic than $\left[(\mathrm{TPP}) \mathrm{Fe}^{\mathrm{III}}\right]_{2}-(\mu-\mathrm{O}) .{ }^{62}$ This is supported by the fact that weaker acids, such as $\mathrm{NH}_{4}{ }^{+}$(Figure 3) and $\mathrm{LutNH}^{+}$(Figure S-5), will also cleave the $\mu$-oxo bridge of 3 . Given that the oxo is coordinated to two Lewis acidic $\mathrm{Fe}^{3+}$ ions, this behavior is surprising. The 
thiolates most likely contribute to this increased basicity. ${ }^{37}$ This is supported by a recent EXAFS study which shows that the cysteinate of chloroperoxidase contributes to an increased basicity of the $\mathrm{Fe}(\mathrm{IV})=\mathrm{O}$ oxo intermediate, resulting in its protonation at physiological $\mathrm{pH} .{ }^{37}$ Chloride-ligated 7 is the final product ${ }^{59}$ observed in the LutNHCl protonation reaction (Figure S-5). When anhydrous acids containing noncoordinating anions, such as $\mathrm{HBF}_{4}$ (Figure S-6), are used to protonate 3 in $\mathrm{MeOH}$ or MeCN, the solventligated complex $\left[\mathrm{Fe}^{\mathrm{III}}\left(\mathrm{S}^{\mathrm{Me} 2} \mathrm{~N}_{4}(\operatorname{tren})\right)(\mathrm{MeCN})\right]^{+}(\mathbf{4})$ or $\left[\mathrm{Fe}^{\mathrm{III}}\left(\mathrm{S}^{\mathrm{Me} 2} \mathrm{~N}_{4}-(\operatorname{tren})\right)(\mathrm{MeOH})\right]^{+}$ forms. ${ }^{42}$ As shown in Figure 3, solvent-ligated 4 also forms when $\mathrm{NH}_{4} \mathrm{PF}_{6}$ is used to protonate the $\mu$-oxo bridge. In noncoordinating solvents, such as THF, on the other hand, protonation of $\mathbf{3}$ using acids containing noncoordinating anions results in loss of the chargetransfer band, bleaching of the solution, and formation of intractable solids, even at low temperatures.

Bridge cleavage in these reactions most likely involves initial protonation of the bridging oxo to afford a transient hydroxo-bridged intermediate. Hydroxo-bridged intermediates are not observed, however, even at low temperatures with only 1 equiv of acid. Although hydroxo-bridged binuclear iron $\left(\mathrm{Fe}^{\mathrm{III}}{ }_{2}\right)$ complexes are known, these are usually only stable when additional bridge supporting ligands (e.g., $\mathrm{RCO}_{2}{ }^{-}, \mathrm{PO}_{4}{ }^{3-}$, etc.) are present. ${ }^{65}$ Unsupported hydroxo diferric bridge structures $\mathrm{Fe}^{\mathrm{III}-}(\mu-\mathrm{OH})-\mathrm{Fe}^{\mathrm{III}}$ are unstable, because significant weakening of the $\mathrm{Fe}-\mathrm{O}$ bonds occurs upon protonation, with a concomitant decrease in magnetic coupling. ${ }^{65}$ Also, the extremely acidic proton on the bridging hydroxy of an $\mathrm{Fe}^{\mathrm{III}-}(\mu-\mathrm{OH})-\mathrm{Fe}^{\mathrm{III}}$ unit usually favors protonation of water to afford $\mathrm{H}_{3} \mathrm{O}^{+}$and the deprotonated $\mu$-oxo $\mathrm{Fe}^{\mathrm{III}}-(\mu-\mathrm{O})-\mathrm{Fe}^{\mathrm{III}}$ core. It is only in the absence of more basic proton acceptor sites that $\mu$-hydroxo-bridged structures are stable. Thus, it is not surprising that the $\mu$-oxo bridge of $\mathbf{3}$ cleaves in MeCN upon the addition of protons. That hydroxide intermediates would be unobservable is consistent with Norton's observation that protonation of bridging-oxos can be surprisingly slow. ${ }^{66}$ If protonation of 3 's oxo is ratelimiting, then one would not expect to see an intermediate hydroxo. Also, given that the oxo of $\mathbf{3}$ is buried within the dimeric core it is not surprising that protonation of the oxo would be slow. It is surprising, however, that the more exposed thiolate ligands of $\mathbf{3}$ are not protonated with stronger acids.

Oxo-bridged binuclear 3 can be regenerated upon the addition of $\mathrm{OH}^{-}$to solvent-ligated $\left[\mathrm{Fe}^{\mathrm{III}}\left(\mathrm{S}^{\mathrm{Me} 2} \mathrm{~N}_{4} \text { (tren))-(MeCN)}\right]^{2+}(\mathbf{4}\right.$; Scheme 3$)$. This reaction is clean, as shown by the isosbestic points in the electronic absorption spectrum shown in Figure 4. Intermediates, such as hydroxide-bound monomeric $\left[\mathrm{Fe}^{\mathrm{III}}\left(\mathrm{S}^{\mathrm{Me} 2} \mathrm{~N}_{4}(\operatorname{tren})\right)(\mathrm{OH})\right]^{+}$, are not observed, even under dilute conditions at low temperatures.

Oxo-bridged 3 is robust toward further oxidative damage by dioxygen or peroxides. Solutions of $\mathbf{3}$ are stable for several weeks in air, and stable (for several minutes) in the presence of a slight excess (1.1 equiv) of hydrogen peroxide. This is in stark contrast to other known $\mathrm{Fe}^{\mathrm{III}}$-thiolates, ${ }^{67-72}$ which readily react with $\mathrm{O}_{2}$ or peroxide to afford metalbound sulfoxides or sulfones, or insoluble rustlike products. Addition of greater than 1.4 equiv of $\mathrm{H}_{2} \mathrm{O}_{2}$ to 3 affords intractable solids even at lower temperatures; no higher valent $\mathrm{Fe}(\mathrm{IV})$ species are observed. ${ }^{63} \mathrm{~A}$ similar result is obtained when pentane solutions of $\mathrm{HOOBu} u^{\mathrm{t}}$ are added to $\mathbf{3}$, even at low temperatures $\left(-90^{\circ} \mathrm{C}\right)$. 


\section{Synthesis of a Sterically Encumbered Ligand Tren-Et ${ }_{4}$}

In an attempt to prevent $\mu$-oxo dimer formation and facilitate the observation of dioxygenbound intermediates, a bulkier version of the tris(2-aminoethyl) amine (tren) ligand was synthesized. Steric bulk has been shown to prevent $\mu$-oxo dimer formation with $\mathrm{N}$-, O-ligated $\mathrm{Fe}(\mathrm{III})$ systems. ${ }^{73-77}$ The most straightforward way to incorporate bulk was to place alkyl substituents on the nitrogens. In order to maintain a single primary amine site for condensation with the thioke-tone arm, and avoid isomeric mixtures, an asymmetrical bis- $N$ substituted tris-amine, $N$-(2-amino-ethyl)- $N$-(2-diethyl-aminoethyl)- $N^{\prime}, N^{\prime}$-diethylethane-1,2-diamine (tren-Et 4 ), was synthesized (as outlined in Scheme 4).

\section{Synthesis and Properties of $\left[\mathrm{Fe}^{\mathrm{Il}}\left(\mathrm{S}^{\mathrm{Me} 2} \mathrm{~N}_{4}(\right.\right.$ tren-Et 4$\left.\left.)\right)\right]\left(\mathrm{PF}_{6}\right)(5)$}

Tertiary amine/thiolate ligated $\left[\mathrm{Fe}^{\mathrm{II}}\left(\mathrm{S}^{\mathrm{Me} 2} \mathrm{~N}_{4}\left(\operatorname{tren}-\mathrm{Et}_{4}\right)\right)\right]-\left(\mathrm{PF}_{6}\right)(\mathbf{5})$ was prepared in a manner analogous to 1 via the metal-templated Schiff-base condensation between 3-methyl-3mercapto-2-butanone and tren-Et $4 .{ }^{42,43}$ Solutions of 5 are chartreuse in MeCN, and characterized by an intense LMCT band at 223(7900) nm, and weak LMCT bands at 314(745) $\mathrm{nm}$ and 330(790) $\mathrm{nm}$. The effective moment of 5 is $4.92 \mu_{\mathrm{B}}$ in MeCN solution indicating that it is high-spin $(S=2)$, and, most likely, mononuclear at ambient temperature. This is supported by its ${ }^{1} \mathrm{H}$ NMR spectrum, which displays paramagnetically shifted peaks in the region 50 to $-20 \mathrm{ppm}$ (Figure S-9). A monomeric structure was ultimately proven by X-ray crystallography. As shown in the ORTEP diagram of Figure 5, tertiary amine-ligated 5 contains $\mathrm{Fe}^{\mathrm{II}}$ in a distorted trigonal bipyramidal coordination environment $(\tau=0.67)^{78}$ similar to that of primary amine-ligated $\mathbf{1}(\tau=0.68)$. Selected geometric parameters of 5 are compared to those of $\mathbf{1}$ in Table 2. The Fe-S bond length (2.317(1) $\AA$ ) in $\mathbf{5}$ is typical for an $\mathrm{Fe}^{\mathrm{II}}$-thiolate bond and is comparable to that of $\mathbf{1}$ (2.328(1) $\AA$; Table 2). The imine Fe-N(1) bond length (Table 2) is also within the normal range. Most notable about the structure of 5 is that the iron amine bonds ( $\mathrm{Fe}-\mathrm{N}(2), \mathrm{Fe}-\mathrm{N}(3)$, and $\mathrm{Fe}-\mathrm{N}(4)$; Table 2) are unusually long. The mean $\mathrm{Fe}-\mathrm{N}(2,3,4)$ bond length is $2.22(3) \AA$, whereas the usual range for $\mathrm{Fe}-\mathrm{N}$ bonds in high-spin $\mathrm{Fe}^{\mathrm{II}}$ amine complexes is $2.00-2.18 \AA{ }^{79-82}$ The trans influence of the thiolate ligand is most likely responsible for the elongation of the apical $\mathrm{Fe}-\mathrm{N}(2)$ bond: this distance is approximately the same in structures $\mathbf{1}$ and $\mathbf{5}$ (Table 2) indicating that the bulky ethyl substituents have very little to do with the observed elongation. The terminal iron-amine bonds $\mathrm{Fe}-\mathrm{N}(3,4)$ (Figure 5; Table 2), on the other hand, are noticeably (0.1 $\mathrm{A}$ ) longer in tertiary amine ligated $\mathbf{5}$ (mean distance $=2.219(1) \AA$ ) versus primary amine ligated $\mathbf{1}$ (mean distance $=2.11(2) \AA$ ), demonstrating that steric bulk, imposed by the ethyl groups, weakens the $\mathrm{Fe}-\mathrm{N}(3,4)$ bonds. Similarly elongated $\mathrm{Fe}(\mathrm{II})-\mathrm{N}$ bonds are observed in the sterically encumbered complexes ( $\left.\mathrm{Mes}_{2} \mathrm{ArCO}_{2}\right)_{2} \mathrm{Fe}^{\mathrm{II}}(\mathrm{TMEDA})_{2}(2.19-(2) \AA),{ }^{83}$ $\left[\mathrm{Fe}^{\mathrm{II}}\left(\mathrm{N}\left(\mathrm{CH}_{2} \mathrm{C}(\mathrm{O}) \mathrm{N}^{\mathrm{t} B u}\right)_{3}\right)\right]^{1-}(2.098(3) \AA),{ }^{84}$ and $\left[\mathrm{Fe}^{\mathrm{II}}(6-\mathrm{Me}-\mathrm{TPA})(\mathrm{MeCN})_{2}\right]^{2+}(2.15(1)$ $\AA) .{ }^{85}$ If this were an electronic effect, then one would expect the tertiary amine $\mathrm{Fe}-\mathrm{N}$ bonds to be shorter (as opposed to longer) than the primary amine $\mathrm{Fe}-\mathrm{N}$ bonds, since tertiary amines are better $\sigma$-donors. That sterics are responsible for the observed elongation of $\mathrm{Fe}-\mathrm{N}$ bonds is supported by recent DFT calculations comparing tertiary versus secondary amine cyclam complexes. ${ }^{86}$ One would expect steric repulsive interactions to be even more problematic in the higher-valent $\mathrm{Fe}$ (III) derivative of $\mathbf{5}$ (vide infra), since the optimum $\mathrm{Fe}(\mathrm{III})-\mathrm{N}$ bond length would require that the tertiary amines move even closer to one 
another. Since reactions between 5 and $\mathrm{O}_{2}$ or $\mathrm{O}_{2}{ }^{-}$involve oxidation of the metal center, the instability of the higher oxidation state would be expected to affect reactivity with these substrates.

\section{Reactivity of [Fe"l( $\left(\mathrm{S}^{\mathrm{Me} 2} \mathrm{~N}_{4}\left(\right.\right.$ tren-Et $\left.\left.\left.\mathrm{t}_{4}\right)\right)\right]\left(\mathrm{PF}_{6}\right)(5)$ with Dioxygen and Superoxide}

In contrast to most $\mathrm{Fe}(\mathrm{II})$ thiolate complexes, ${ }^{55,69,71,72,80,87-91}$ thiolate-ligated $\left[\mathrm{Fe}^{\mathrm{II}}\left(\mathrm{S}^{\mathrm{Me} 2} \mathrm{~N}_{4}\left(\right.\right.\right.$ tren- $\left.\left.\left.\mathrm{Et}_{4}\right)\right)\right]\left(\mathrm{PF}_{6}\right)(\mathbf{5})$ does not react with dioxygen. Solutions of $\mathbf{5}$ are stable in air for hours. Complex 1, on the other hand, reacts rapidly (within seconds) with dioxygen at ambient temperature to cleanly afford the stable $\mu$-oxo dimer $\mathbf{3}$. Also in contrast to primary amine ligated $\mathbf{1}$, tertiary amine-ligated $\mathbf{5}$ does not react readily with superoxide. When $\mathrm{KO}_{2}$ (solubilized as its 18-crown-6 salt) is injected into an $\mathrm{MeCN}$ solution of $\mathbf{5}$, there is no immediate reaction. Instead, 5 gradually (over $30 \mathrm{~min}$ at $-20^{\circ} \mathrm{C}$ ) converts to an intractable deep-brown oily solid. Complex 1, on the other hand, reacts rapidly (at diffusion controlled rates) with $\mathrm{O}_{2}{ }^{-}$to afford an $\mathrm{Fe}^{\mathrm{III}}-\mathrm{OOH}$ intermediate. ${ }^{43}$ Initially, it was thought that the absence of $\mathrm{N}-\mathrm{H}$ protons in $\mathbf{5}$ was responsible for its sluggish reactivity with $\mathrm{O}_{2}^{-}$, and the mechanism was thought to involve $\mathrm{H}$-atom abstraction. However, this mechanism was ruled out by the fact that no reaction occurs between primary amine-ligated $\mathbf{1}$ and superoxide in rigorously dried THF, in the absence of an external proton donor. ${ }^{49}$ Alternatively, the Etgroups alter reactivity by modifying the steric and electronic properties of the metal center. More specifically, one would expect the frontier orbitals involved in binding and activating superoxide, and the stability of the $\mathrm{Fe}(\mathrm{III})$-peroxide intermediate, to be perturbed by the Etsubstituents of $\mathbf{5}$.

In order to assess the stability of the oxidized Fe(III) derivative of $\mathbf{5}$, both the chemical oxidation of 5 (using NO- $\left(\mathrm{PF}_{6}\right)$ ), and a direct synthetic route to $\left[\mathrm{Fe}^{\mathrm{III}}\left(\mathrm{S}^{\mathrm{Me} 2} \mathrm{~N}_{4}\left(\operatorname{tren}-\mathrm{Et}_{4}\right)\right)\right]^{2+}$ (via the insertion of $\mathrm{Fe} \mathrm{III}^{\mathrm{II}}$ into the $\left[\left(\text { tren- } \mathrm{Et}_{4}\right) \mathrm{N}_{4} \mathrm{~S}^{\mathrm{Me} 2}\right]^{1-}$ ligand), were attempted. Both of these methods resulted only in the formation of intractable solids. Unfavorable steric repulsive interactions between the bulky ethyl groups are most likely responsible for this instability. This is supported by the crystal structure of reduced $\mathbf{5}$ which revealed (vide supra) that steric repulsive forces do not allow the nitrogens to attain their idealized $\mathrm{Fe}^{\mathrm{II}}-\mathrm{N}$ bond length, resulting in unusually long $\mathrm{Fe}^{\mathrm{II}}-\mathrm{N}(\mathrm{Et})_{2}$ bonds. These repulsive forces would increase prohibitively as the nitrogens moved closer to the metal ion in an attempt to adopt the optimized Fe ${ }^{\mathrm{III}}-\mathrm{N}$ bond length. Thus, it would appear that the $\left[\left(\operatorname{tren}-\mathrm{Et}_{4}\right)-\mathrm{N}_{4} \mathrm{~S}^{\mathrm{Me} 2}\right]^{1-}$ ligand is unable to accommodate iron in the $\mathrm{Fe}^{3+}$ oxidation state. Similar behavior is seen with $\left[\mathrm{Fe}^{\mathrm{II}}(6-\mathrm{Me}-\mathrm{TPA})(\mathrm{MeCN})_{2}\right]^{2+}(\mathbf{8}),{ }^{85}$ and $\left[\mathrm{Fe}^{\mathrm{II}}\left(\mathrm{N}\left(\mathrm{CH}_{2} \mathrm{C}(\mathrm{O}) \mathrm{N}^{\mathrm{t}} \mathrm{Bu}\right)_{3}\right)\right]^{1-84}$ where steric repulsive forces disfavor shorter bonds and higher oxidation states, resulting in cathodically shifted redox potentials. Introduction of a methyl group on one of the pyridine rings of the TPA ligand of 8 causes the Fe(II)-N bonds to elongate by $0.16 \AA$ (from 1.99(1) to 2.15(1) $\AA$ ) relative to the unsubstituted ligand. The redox potential of $\mathbf{5}\left(E_{\mathrm{p}}^{\mathrm{a}}\right.$; irrev) is also cathodically shifted (from $-100 \mathrm{mV}$ with primary amine-ligated 1 to $E_{\mathrm{p}}{ }^{\mathrm{a}}=+410 \mathrm{mV}$ with tertiary amine-ligated 5 (Figure 6)). This indicates that the $\mathrm{Fe}^{3+}$ oxidation state is $\sim 12$ $\mathrm{kcal} / \mathrm{mol}$ less stable in the tertiary amine ligand $\left[\left(\text { tren- }-\mathrm{Et}_{4}\right) \mathrm{N}_{4} \mathrm{~S}^{\mathrm{Me} 2}\right]^{1-}$ relative to the primary amine ligand $\left[(\operatorname{tren}) \mathrm{N}_{4} \mathrm{~S}^{\mathrm{Me} 2}\right]^{1-}$. Furthermore, the cyclic voltammogram wave associated with 5 (Figure 6) is irreversible indicating that the $\mathrm{Fe}^{\mathrm{III}}$ derivative, once generated, rapidly (on the order of seconds) decomposes. This instability of $\mathrm{Fe}^{\mathrm{III}}$ in the $\left[\left(\text { tren- } \mathrm{Et}_{4}\right) \mathrm{N}_{4} \mathrm{~S}^{\mathrm{Me} 2}\right]^{1-}$ 
ligand is unusual in that thiolates typically stabilize iron in higher oxidation states. ${ }^{6}$ This is demonstrated by the rather anodic redox potentials ( -400 to $-1000 \mathrm{mV}$ vs SCE) of Fe $\mathrm{FiI}_{-}$ thiolate complexes. ${ }^{68,90,92-94}$ The instability of $\mathrm{Fe}^{\mathrm{III}}$ in the $\left[\left(\text { tren- }-\mathrm{Et}_{4}\right)-\mathrm{N}_{4} \mathrm{~S}^{\mathrm{Me} 2}\right]^{1-}$ ligand thus explains the lack of reactivity between 5 and $\mathrm{O}_{2}$ or $\mathrm{O}_{2}^{-}$.

\section{Summary and Conclusions}

This work describes the reaction between five-coordinate, thiolate-ligated $\left[\mathrm{Fe}^{\mathrm{II}}\left(\mathrm{S}^{\mathrm{Me} 2} \mathrm{~N}_{4}(\text { tren })\right)\right]^{+}(\mathbf{1})$ and dioxygen to afford a rare example of a $\mu$-oxo dimer containing a thiolate in the coordination sphere, $\left[\mathrm{Fe}^{\mathrm{III}}\left(\mathrm{S}^{\mathrm{Me} 2} \mathrm{~N}_{4}(\operatorname{tren})\right)\right]_{2}\left(\mu^{2}-\mathrm{O}\right)^{2+}(\mathbf{3})$. An intermediate is detected in this reaction at low temperatures, suggesting that this reaction involves the initial coordination of $\mathrm{O}_{2}$ to the open coordination site at iron. In a related reaction, superoxide $\left(\mathrm{O}_{2}^{-}\right)$has been shown to oxidatively add to this site at low temperatures to afford a spectroscopically detectable $\mathrm{Fe}^{\mathrm{III}}-\mathrm{OOH}$ intermediate. Although the thiolate does not appear to noticeably perturb the metrical parameters of $\mu$-oxo-bridged $\mathbf{3}$, it does decrease the magnetic coupling between the two iron centers and creates a rather basic oxo site. Protonation of this oxo using strong $\left(\mathrm{HBF}_{4}, \mathrm{HCl}\right)$ or weak $\left(\mathrm{HOAc}, \mathrm{NH}_{4} \mathrm{PF}_{6}, \mathrm{LutNHCl}\right)$ acids results in $\mu$-oxo bridge cleavage to afford the corresponding solvent- or anion-bound monomeric derivatives. That the $\mu$-hydroxo-bridged intermediate is not detected in these protonation reactions is not suprising, given that protonated $\mu$-hydroxo-bridged species tend to be unstable in the absence of additional bridging ligands. Mechanisms of $\mu$-oxo dimer formation have been shown to involve peroxide and high-valent oxo intermediates. An attempt to stabilize these intermediates in the reaction affording 3 by increasing steric bulk instead creates a ligand $\left(\left[\left(\text { tren- }-\mathrm{Et}_{4}\right) \mathrm{N}_{4} \mathrm{~S}^{\mathrm{Me} 2}\right]^{1-}\right)$ that alters the electronic properties of the iron to the point where $\mathrm{O}_{2}$ oxidation chemistry is no longer favored.

\section{Supplementary Material}

Refer to Web version on PubMed Central for supplementary material.

\section{Acknowledgment}

J.S. wishes to thank the EPA for a graduate fellowship (91594801-0). NIH support (Grant GM 45881) is gratefully acknowledged.

\section{References}

1. Costas M, Mehn MP, Jensen MP, Que L Jr. Chem. Rev. 2004; 104:939-986. [PubMed: 14871146]

2. Waller BJ, Lipscomb JD. Chem. Rev. 1996; 96:2625-2657. [PubMed: 11848839]

3. Que L Jr, Ho RYN. Chem. Rev. 1996; 96:2607-2624. [PubMed: 11848838]

4. Feig AL, Lippard SJ. Chem. Rev. 1994; 94:759-805.

5. Solomon EI, Brunold TC, Davis MI, Kemsley JN, Lee S, Lehnert N, Neese F, Skulan AJ, Yang Y, Ahou J. Chem. Rev. 2000; 100:235-350. [PubMed: 11749238]

6. Kovacs JA. Chem. Rev. 2004; 104:825-848. [PubMed: 14871143]

7. Kovacs JA. Science. 2003; 299:1024-1025. [PubMed: 12586930]

8. Pellegrini M, Liehr IS, Fisher AL, Laub PB, Cooperman BS, Mierke DF. Biochemistry. 2000; 39:12210-12215. [PubMed: 11015199]

9. Kappock TJ, Caradonna JP. Chem. Rev. 1996; 96:2659-2756. [PubMed: 11848840] 
10. Prigge ST, Boyington JC, Faig M, Doctor KS, Gaffney BJ, Amzel LM. Biochimie. 1997; 79:629_ 636. [PubMed: 9479444]

11. Nelson MJ, Seitz SP. Curr. Opin. Struct. Biol. 1994; 4:878-884. [PubMed: 7712291]

12. Goldsmith CR, Jonas RT, Stack TDP. J. Am. Chem. Soc. 2002; 124:83-96. [PubMed: 11772065]

13. Rocklin AM, Tierney DL, Kofman V, Brunhuber NMW, Hoffman BM, Christoffersen RE, Reich NO, Lipscomb JD, Que L Jr. Proc. Natl. Acad. Sci. U.S.A. 1999; 96:7905-7909. [PubMed: 10393920]

14. Hausinger RP. Crit. Rev. Biochem. Mol. Biol. 2004; 39:1-47. [PubMed: 15121719]

15. Mascharak PK. Coord. Chem. Rev. 2002; 225:201-214.

16. Yeh AP, Hu Y, Jenney FE Jr, Adams MWW, Rees DC. Biochemistry. 2000; 39:2499-2508. [PubMed: 10704199]

17. Mathe C, Mattioli TA, Horner O, Lombard M, Latour J-M, Fontecave M, Niviere V. J. Am. Chem. Soc. 2002; 124:4966-4967. [PubMed: 11982354]

18. Nivie`re V, Asso M, Weill CO, Lombard M, Guigliarelli B, Favaudon V, Houeé-Levin C. Biochemistry. 2004; 43:808-818. [PubMed: 14730986]

19. Coulter ED, Emerson JP, Kurtz DM Jr, Cabelli DE. J. Am. Chem. Soc. 2000; 122:11555-11556.

20. Jenney FE Jr, Verhagen MFJM, Cui X, Adams MWW. Science. 1999; 286:306-309. [PubMed: 10514376]

21. Lombard M, Houee-Levin C, Touati D, Fontecave M, Niviere V. Biochemistry. 2001; 40:50325040. [PubMed: 11305919]

22. Niviere V, Lombard M, Fontecave M, Houee-Levin C. FEBS Lett. 2001; 497:171-173. [PubMed: 11377434]

23. Coelho AV, Matias P, Fulop V, Thompson A, Gonzalez A, Carrondo MA. J. Biol. Inorg. Chem. 1997; 2:680-689.

24. Becker A, Schlichting I, Kabsch W, Groche D, Schultz S, Wagner AFV. Nat. Struct. Biol. 1998; 5:1053-1058. [PubMed: 9846875]

25. Rajagopalan PTR, Yu XC, Pei D. J. Am. Chem. Soc. 1997; 119:12418-12419.

26. Loew GH, Harris DL. Chem. Rev. 2000; 100:407-419. [PubMed: 11749241]

27. Harris DL, Loew GH. J. Am. Chem. Soc. 1998; 120:8941-8948.

28. Sono M, Roach MP, Coulter ED, Dawson JH. Chem. Rev. 1996; 96:2841-2887. [PubMed: 11848843]

29. Schlichting I, Berendzen J, Chu K, Stock AM, Maves SA, Benson DE, Sweet RM, Ringe D, Petsko GA, Sligar SG. Science. 2000; 287:1615-1622. [PubMed: 10698731]

30. Auclair K, Moënne-Loccoz P, Ortiz de Montellano PR. J. Am. Chem. Soc. 2001; 123:4877-4885. [PubMed: 11457314]

31. Ogliaro F, deVisser SP, Cohen S, Sharma PK, Shaik S. J. Am. Chem. Soc. 2002; 124:2806-2817. [PubMed: 11890833]

32. Clay M, Cosper CA, Jenney FE Jr, Adams MWW, Johnson MK. Proc. Natl. Acad. Sci. U.S.A. 2003; 100:3796-3801. [PubMed: 12655067]

33. Que L Jr. Nat. Struct. Biol. 2000; 7:182-184. [PubMed: 10700270]

34. Neese F, Zaleski JM, Zaleski KL, Solomon EI. J. Am. Chem. Soc. 2000; 122:11703-11724.

35. Rohde J-U, In J-H, Lim MH, Brennessel WW, Bukowski MR, Stubna A, Munck E, Nam W, Que L Jr. Science. 2003; 299:1037-1039. [PubMed: 12586936]

36. Decker A, Rohde J-U, Que L Jr, Solomon EI. J. Am. Chem. Soc. 2004; 126:5378-5379. [PubMed: 15113207]

37. Green MT, Dawson JH, Gray HB. Science. 2004; 304:1653-1656. [PubMed: 15192224]

38. Urano Y, Higuchi T, Hirobe M, Nagano T. J. Am. Chem. Soc. 1997; 119:12008-12009.

39. Higuchi T, Shimada K, Maruyama N, Hirobe M. J. Am. Chem. Soc. 1993; 115:7551-7552.

40. Rapael AL, Gray HB. J. Am. Chem. Soc. 1991; 113:1038-1040.

41. Matsui T, Nagano S, Ishimori K, Watanabe Y, Morishima I. Biochemistry. 1996; 35:13118-13124. [PubMed: 8855949] 
42. Shearer J, Nehring J, Kaminsky W, Kovacs JA. Inorg. Chem. 2001; 40:5483-5484. [PubMed: 11599942]

43. Shearer J, Scarrow RC, Kovacs JA. J. Am. Chem. Soc. 2002; 124:11709-11717. [PubMed: 12296737]

44. Silaghi-Dumitrescu R, Silaghi-Dumitrescu I, Coulter ED, Kurtz DM Jr. Inorg. Chem. 2003; 42:446-456. [PubMed: 12693226]

45. Dey A, Chow M, Theisen RM, Kovacs JA, Solomon EI. Manuscript in preparation.

46. Evans DA. J. Chem. Soc. 1959:2005.

47. Live DH, Chan SI. Anal. Chem. 1970; 42:791.

48. Van Geet AL. Anal. Chem. 1968; 40:2227-2229.

49. Theisen RM, Kovacs JA. Inorg. Chem. submitted.

50. Mukherjee RN, Stack TDP, Holm RH. J. Am. Chem. Soc. 1988; 110:1850-1861.

51. Kurtz DM Jr. Chem. Rev. 1990; 90:585-606.

52. Musie G, Lai C-H, Reibenspies JH, Sumner LW, Darensbourg MY. Inorg. Chem. 1998; 37:40864093. [PubMed: 11670528]

53. Roelfes G, Lubben M, Chen K, Ho RYN, Mettsma A, Genseberger S, Hermant RM, Hage R, Mandal SK, Young VG Jr, Zang Y, Kooijman H, Spek AL, Que L Jr, Feringa BL. Inorg. Chem. 1999; 38:1929-1936. [PubMed: 11670967]

54. Norman RE, Holz RC, Menage S, O’Connor CJ, Zhang JH, Que L Jr. Inorg. Chem. 1990; 29:4629-4637.

55. Grapperhaus CA, Li M, Patra AK, Poturovic S, Kozlowski PM, Zgierski MZ, Mashuta MS. Inorg. Chem. 2003; 42:4382-4388. [PubMed: 12844310]

56. Grapperhaus CA, Darensbourg MY. Acc. Chem. Res. 1998:31, 1451-459.

57. Chin D-H, La Mar GN, Balch AL. J. Am. Chem. Soc. 1980; 102:4344-4350.

58. Balch AL, Chan Y-W, Cheng R-J, La Mar GN, Latos-Grazynski L, Renner MW. J. Am. Chem. Soc. 1984; 106:7779-7785.

59. Villar G, Fitch S, Horner O, Latour J-M, Kovacs JA. Manuscript in preparation.

60. Shearer J, Fitch SB, Kaminsky W, Benedict J, Scarrow RC, Kovacs JA. Proc. Natl. Acad. Sci. U.S.A. 2003; 100:3671-3676. [PubMed: 12655068]

61. Ostfeld D, Colfax JA. Inorg. Chem. 1978; 17:1796-1799.

62. Evans DR, Reed CA. J. Am. Chem. Soc. 2000; 122:4660-4667.

63. Que L Jr, Tolman WB. Angew. Chem., Int. Ed. 2002; 41:1114-1137.

64. Almarsson O, Adalsteinsson H, Bruice TC. J. Am. Chem. Soc. 1995; 117:4524-4532.

65. Armstrong WH, Lippard SJ. J. Am. Chem. Soc. 1984; 106:4632-4633.

66. Carroll MM, Norton JR. J. Am. Chem. Soc. 1992; 114:8744-8745.

67. Tyler LA, Noveron JC, Olmstead MM, Mascharak PK. Inorg. Chem. 1999; 38:616-617.

68. Jackson HL, Shoner SC, Rittenberg D, Cowen JA, Lovell S, Barnhart D, Kovacs JA. Inorg. Chem. 2001; 40:1646-1653. [PubMed: 11261975]

69. Govindaswamy N, Quarless DA Jr, Koch SA. J. Am. Chem. Soc. 1995; 117:8468-69.

70. Millar M, Lee JF, Koch SA, Fikar R. Inorg. Chem. 1982; 21:4105-6.

71. Herskovitz T, Depamphilis BV, Gillum WO, Holm RH. Inorg. Chem. 1975; 14:1426-30.

72. Lane RW, Ibers JA, Frankel RB, Papaefthymiou GC, Holm RH. J. Am. Chem. Soc. 1977; 99:8498. [PubMed: 830690]

73. Collman JP, Gagne RR, Halbert TR, Marchon JC, Reed CA. J. Am. Chem. Soc. 1973; 95:78687870. [PubMed: 4759037]

74. MacBeth CE, Golombek AP, Young VG Jr, Yang C, Kuczera K, Hendrich MP, Borovik AS. Science. 2000; 289:938-941. [PubMed: 10937994]

75. Ogo S, Wada S, Watanabe Y, Iwase M, Wada A, Harata M, Jitsukawa K, Masuda H, Einaga H. Angew. Chem., Int. Ed. Engl. 1998; 37:2102-2104.

76. Yeh C-Y, Chang CJ, Nocera DG. J. Am. Chem. Soc. 2001; 123:1513-1514. [PubMed: 11456732]

77. Shirin Z, Young VG Jr, Borovik AS. Chem. Commun. 1997:1967-1968. 
78. Addison AW, Rao TN, Reedijk J. J. Chem. Soc., Dalton Trans. 1984:1349.

79. Boeyens JCA, Forbes AGS, Hancock RD, Wieghardt K. Inorg. Chem. 1985; 24:2926-2931.

80. Shoner SC, Nienstedt A, Ellison JJ, Kung I, Barnhart D, Kovacs JA. Inorg. Chem. 1998; 37:57215725.

81. Matouzenko GS, Bousseksou A, Borshch SA, Perrin M, Zein S, Salmon L, Molnar G, Lecocq S. Inorg. Chem. 2004:227-236. [PubMed: 14704072]

82. Di Vaira M, Ghilardi CA, Sacconi L. Inorg. Chem. 1976; 15:1955.

83. Hagadorn JR, Que L Jr, Tolman WB. Inorg. Chem. 2000; 39:6086-6090. [PubMed: 11188526]

84. Ray M, Hammes B, Yap GPA, Rheingold AL, Borovik AS. Inorg. Chem. 1998; 37:1527-1532.

85. Zang Y, Kim J, Dong Y, Wilkinson EC, Appelman EH, Que L Jr. J. Am. Chem. Soc. 1997:41974205.

86. Clark T, Hennemann M, Eldik Rv, Meyerstein D. Inorg. Chem. 2002; 41:2927-2935. [PubMed: 12033901]

87. Hagen KS, Holm RH. J. Am. Chem. Soc. 1982; 104:5496-7.

88. Millar M, Lee JF, Fikar R. Inorg. Chim. Acta. 1996; 243:333.

89. Shoner S, Barnhart D, Kovacs JA. Inorg. Chem. 1995; 34:4517-18.

90. Noveron JC, Olmstead MM, Mascharak PK. J. Am. Chem. Soc. 2001; 123:3247-3259. [PubMed: 11457060]

91. Artaud I, Chatel S, Chauvin AS, Bonnet D, Kopf MA, Leduc P. Coord. Chem. Rev. 1999; 190-192:577-586.

92. Mascharak PK, Harrop TC. Acc. Chem. Res. 2004; 37:253-260. [PubMed: 15096062]

93. Beissel T, Buerger KS, Voigt G, Wieghardt K, Butzlaff C, Trautwein AX. Inorg. Chem. 1993; 32:124-6.

94. Noveron JC, Olmstead MM, Mascharak PK. Inorg. Chem. 1998; 37:1138-1139. [PubMed: 11670316] 


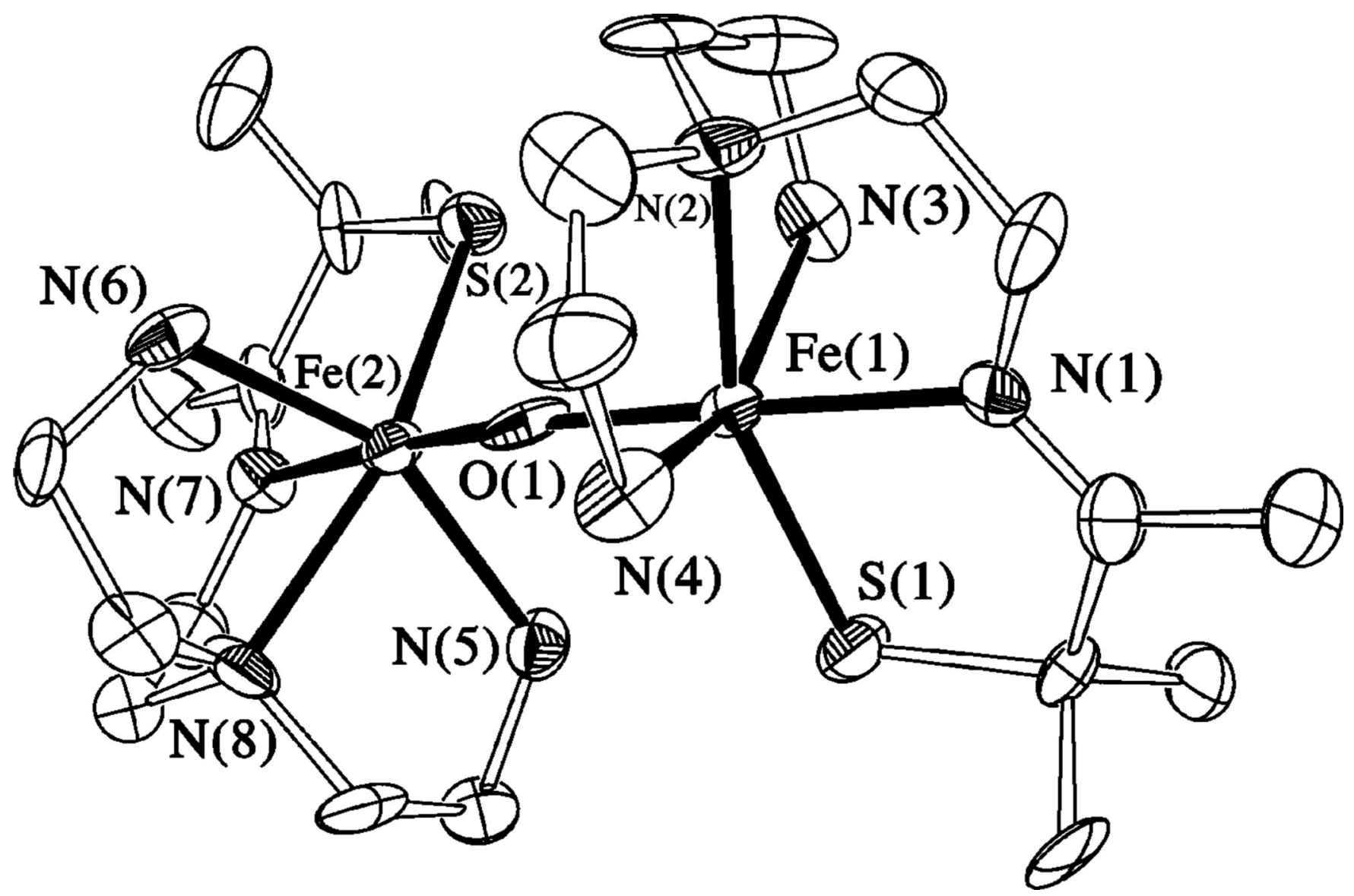

Figure 1.

ORTEP of the $\mu$-oxo dimer $\left[\mathrm{Fe}^{\mathrm{III}}\left(\mathrm{S}^{\mathrm{Me} 2} \mathrm{~N}_{4}(\text { tren })\right)\right]_{2} \mu^{-} \mathrm{O}^{2+}(\mathbf{3})$ and atom labeling scheme. All hydrogen atoms have been removed for clarity. 


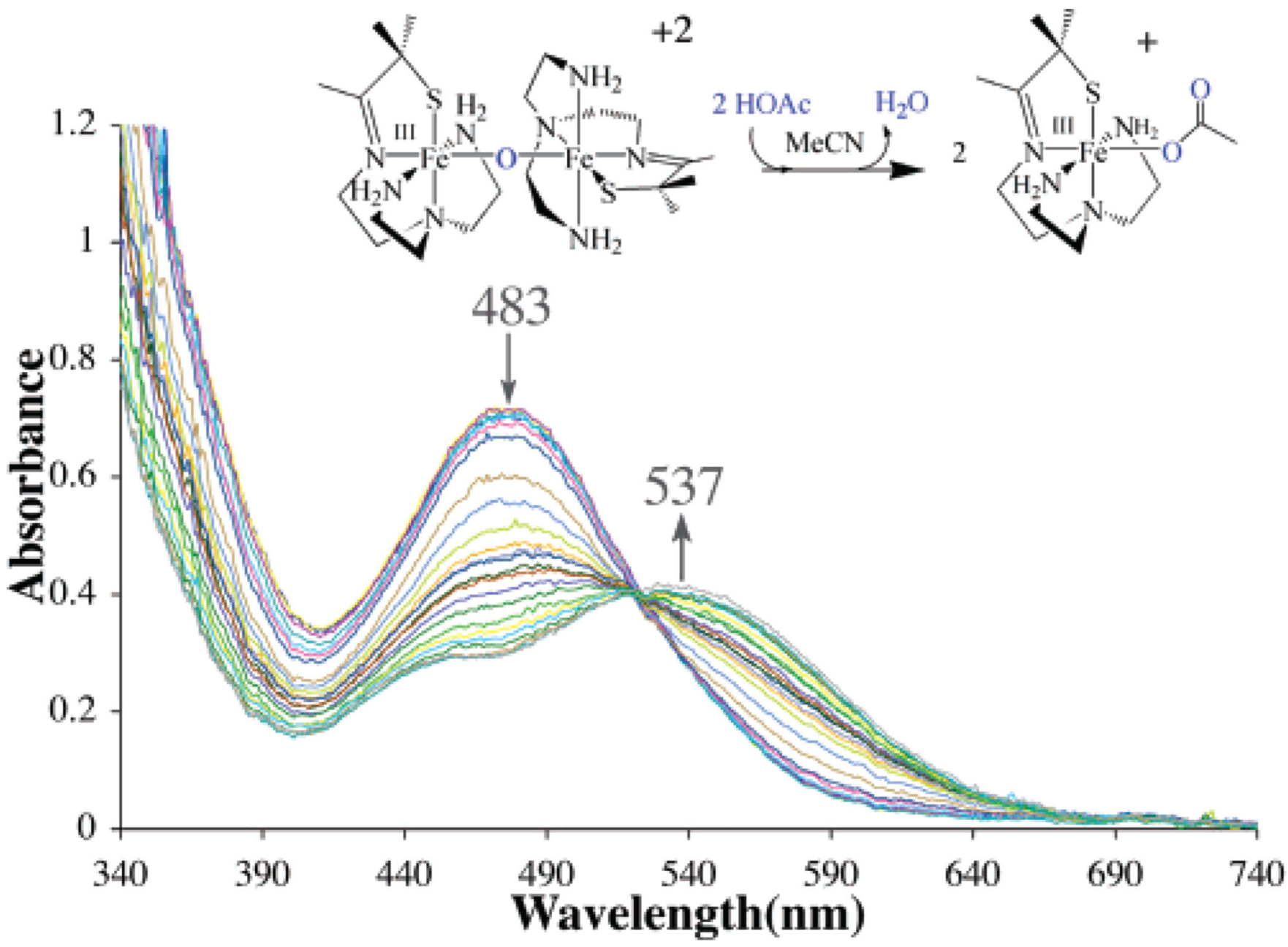

Figure 2.

Electronic absorption spectrum showing that the $\mu$-oxo bridge of dimeric $\mathbf{3}$ is cleaved upon the addition of 2 equiv of HOAc in MeCN solvent to cleanly afford monomeric $\left[\mathrm{Fe}^{\mathrm{III}}\left(\mathrm{S}^{\mathrm{Me} 2} \mathrm{~N}_{4}(\text { tren })\right)(\mathrm{OAc})\right]^{+}(\mathbf{6})$. 


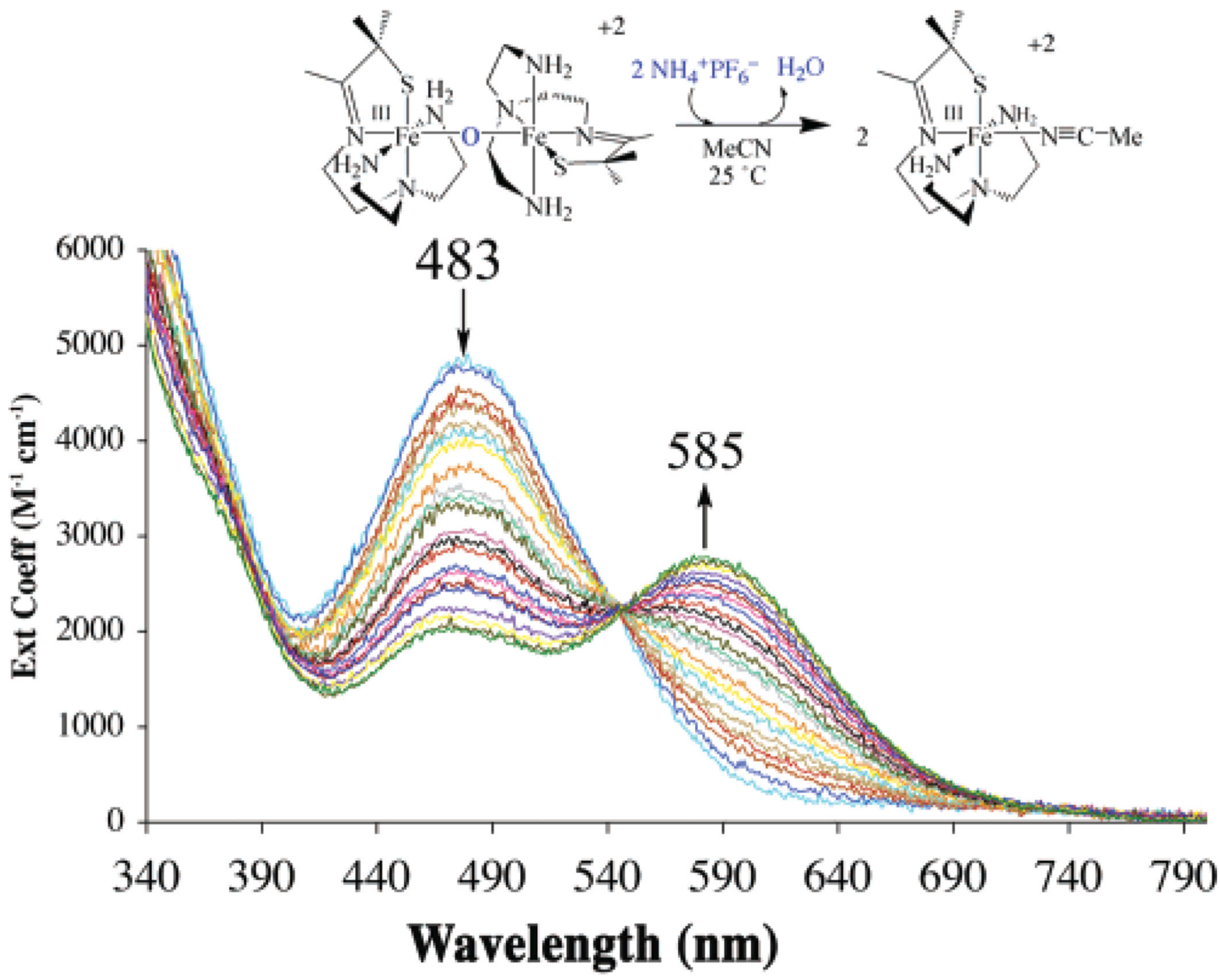

Figure 3.

Electronic absorption spectrum showing that the $\mu$-oxo bridge of dimeric 3 is cleaved upon the addition of 2 equiv of $\mathrm{NH}_{4} \mathrm{PF}_{6}$ in $\mathrm{MeCN}$ solvent to cleanly afford monomeric solventligated $\left[\mathrm{Fe}^{\mathrm{III}}\left(\mathrm{S}^{\mathrm{Me} 2} \mathrm{~N}_{4}(\text { tren })\right)-(\mathrm{MeCN})\right]^{+2}(\mathbf{4})$. 


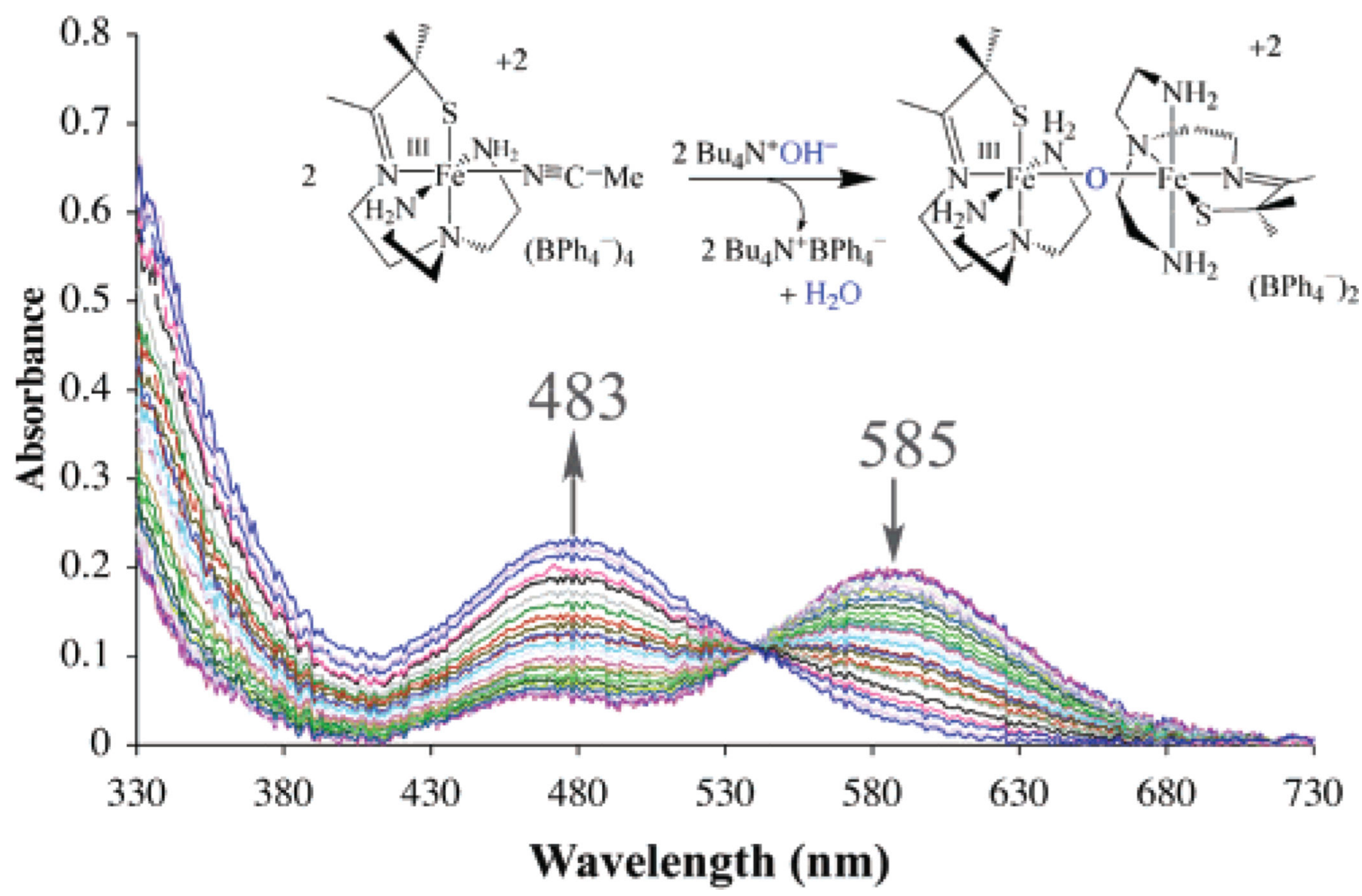

Figure 4.

Electronic absorption spectrum showing that reaction of 2 equiv of $\mathrm{Bu}_{4} \mathrm{NOH}$ with monomeric $\left[\mathrm{Fe}^{\mathrm{III}}\left(\mathrm{S}^{\mathrm{Me} 2} \mathrm{~N}_{4}(\text { tren })\right)(\mathrm{MeCN})\right]^{+2}$ (4) in MeCN affords the $\mu$-oxo dimer $\left[\mathrm{Fe}^{\mathrm{III}}\left(\mathrm{S}^{\mathrm{Me} 2} \mathrm{~N}_{4}(\text { tren })\right)\right]_{2} \mu-\mathrm{O}^{2+}(\mathbf{3})$ at ambient temperature. 


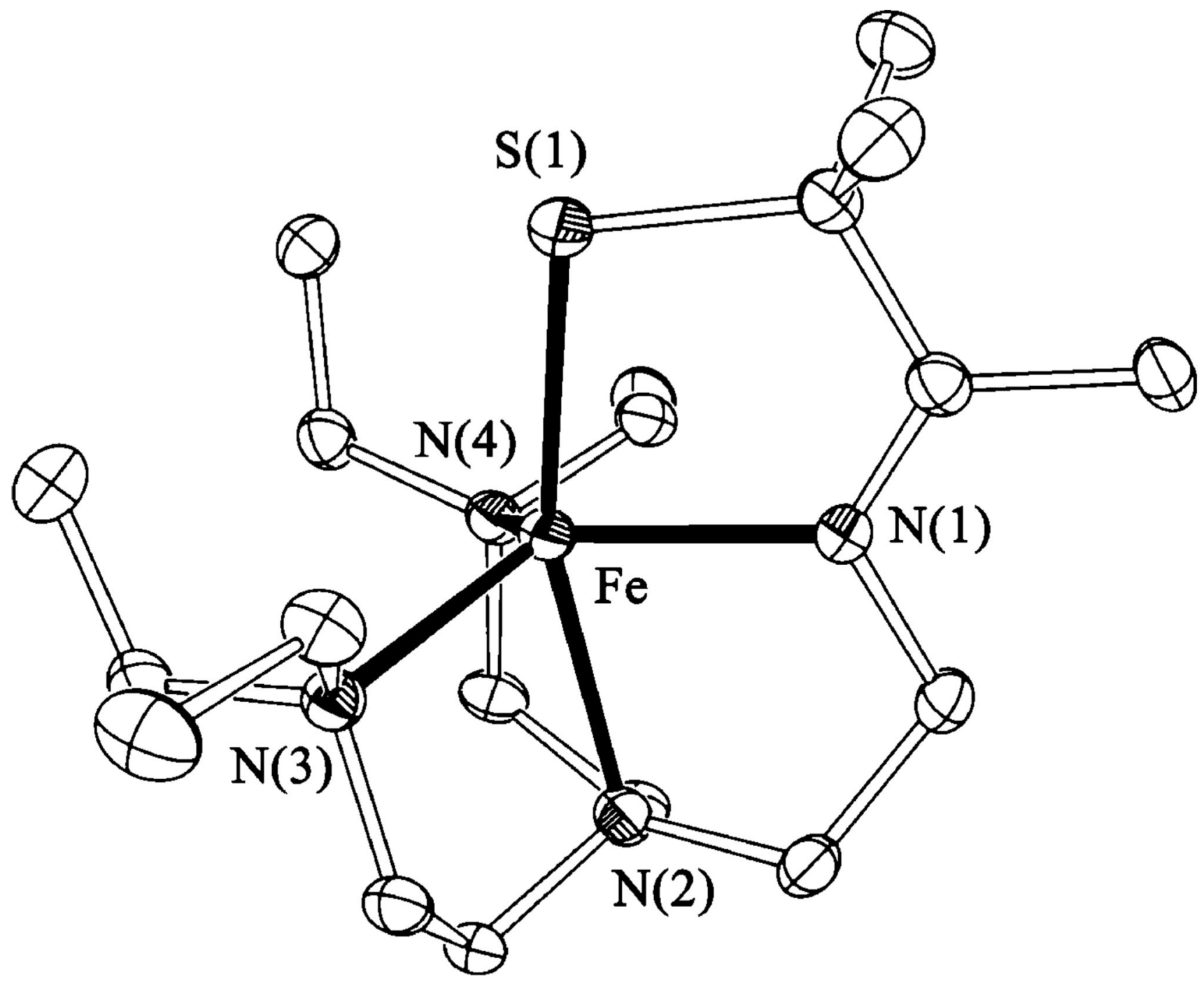

Figure 5.

ORTEP of the ferrous complex $\left[\mathrm{Fe}^{\mathrm{II}}\left(\mathrm{S}^{\mathrm{Me} 2} \mathrm{~N}_{4}(\text { tren-Et } 4)\right)\right]^{+}(\mathbf{5})$ and atom labeling scheme. All hydrogen atoms have been removed for clarity. 


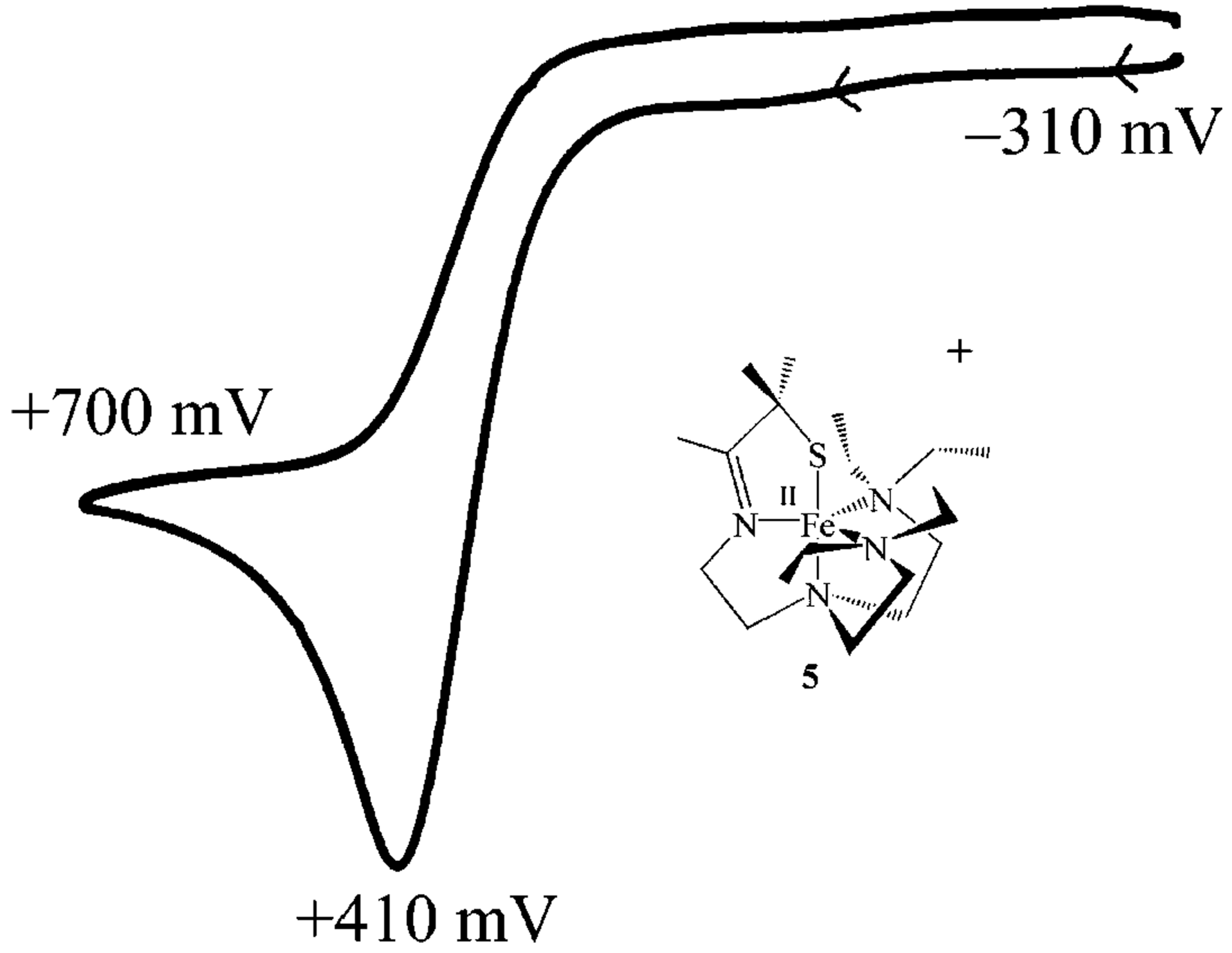

Figure 6.

Cyclic voltammogram of $\left[\mathrm{Fe}^{\mathrm{II}}\left(\mathrm{S}^{\mathrm{Me} 2} \mathrm{~N}_{4}(\text { tren-Et } 4)\right)\right]^{+}(\mathbf{5})$ in $\mathrm{MeCN}$, with $\mathrm{Bu}_{4} \mathrm{~N}\left(\mathrm{PF}_{6}\right)$ supporting electrolyte $(0.100 \mathrm{M})$, over the range +700 to $-300 \mathrm{mV}$ vs SCE. 
Theisen et al.

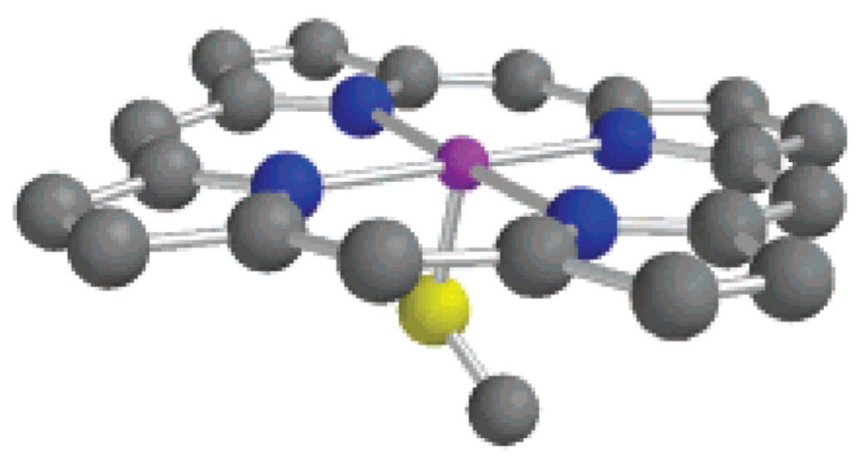

cytochrome P450
Page 22

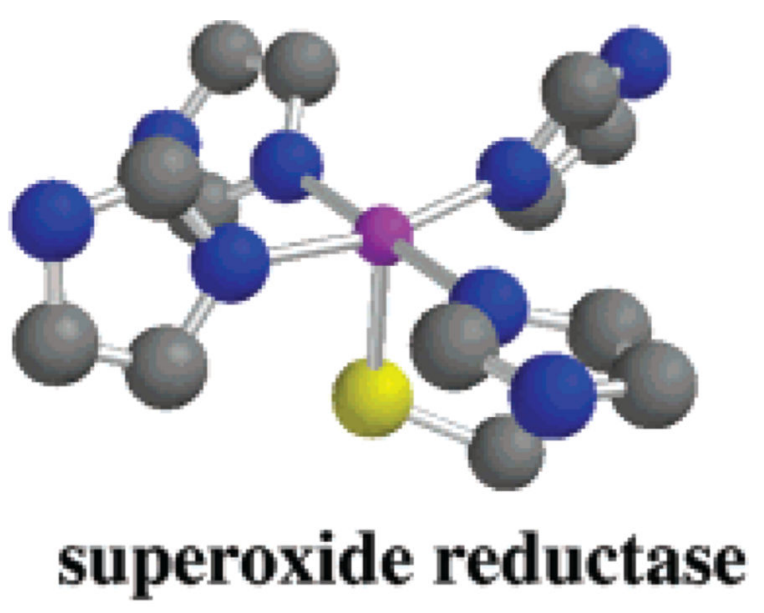

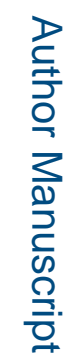

Scheme 1.

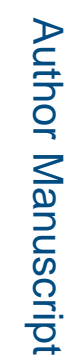

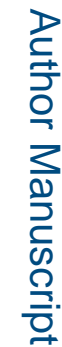

Inorg Chem. Author manuscript; available in PMC 2015 June 28. 
(a)

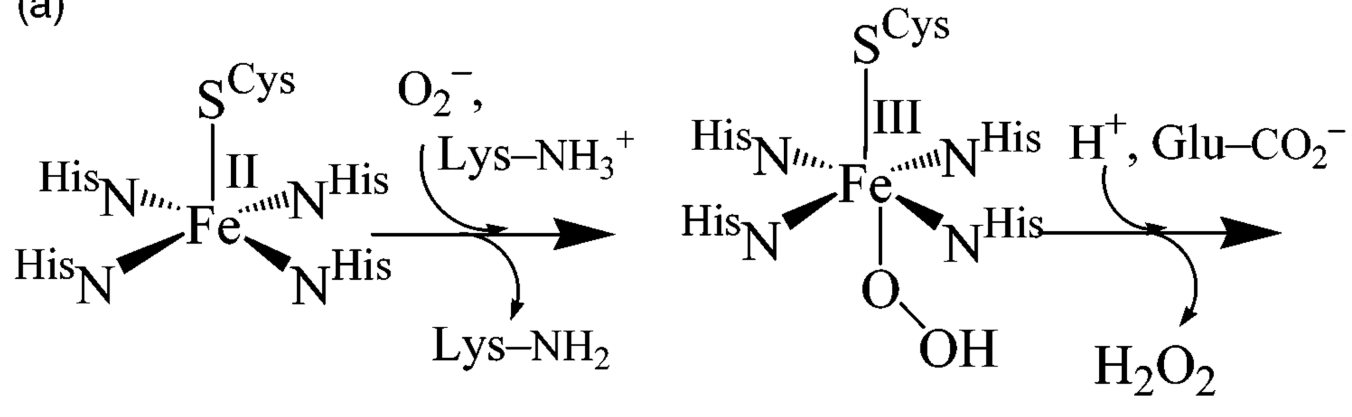

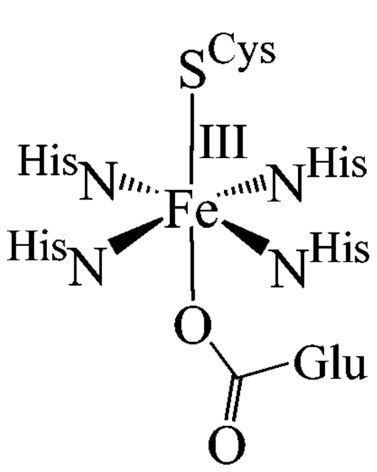

(b)

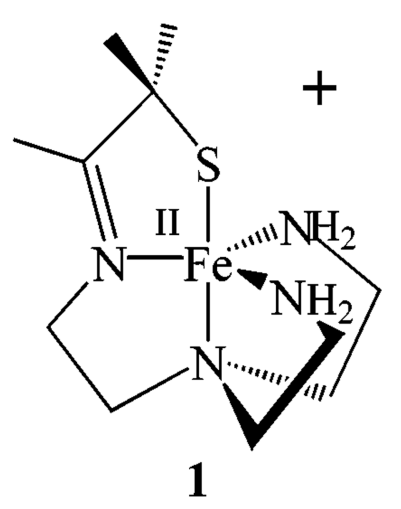

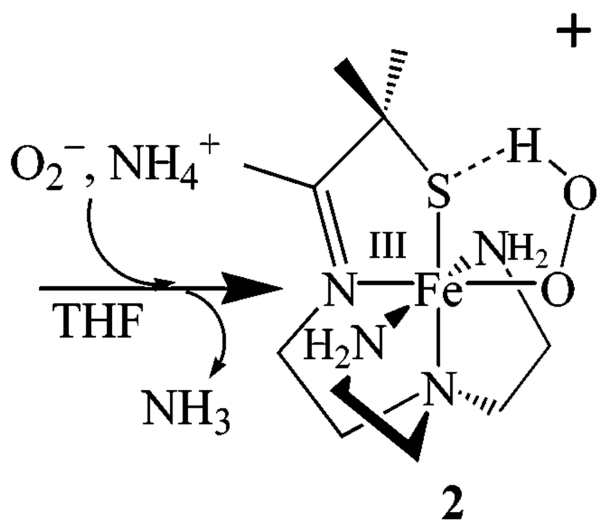<smiles>CC(C)(CO)C(=O)O</smiles>

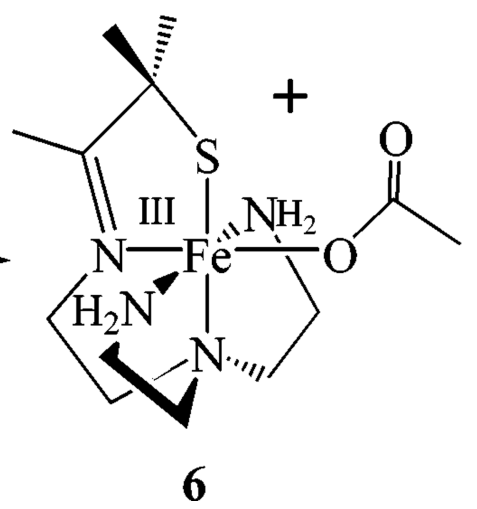

Scheme 2. 
Theisen et al.
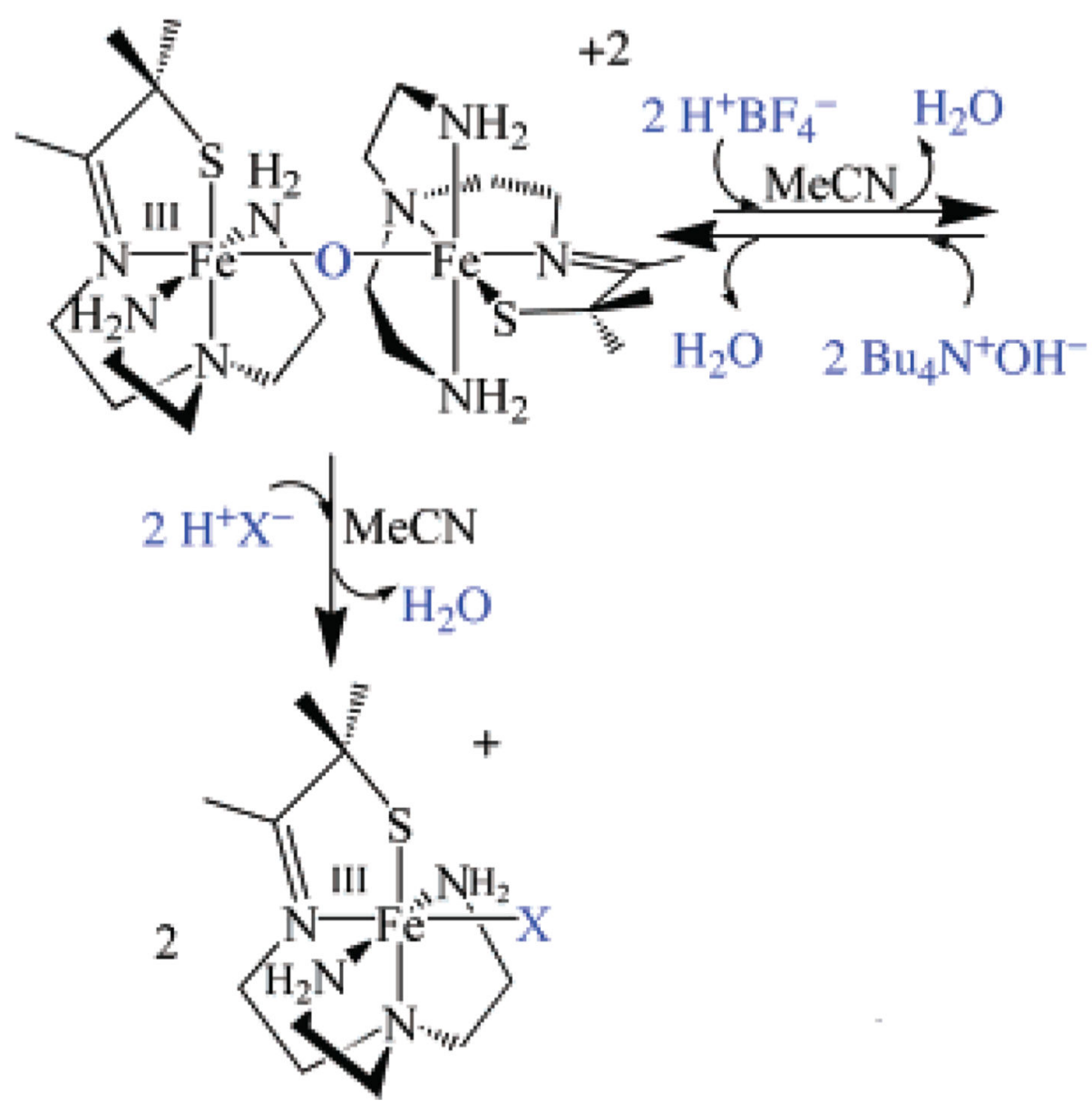

Scheme 3.
Page 24

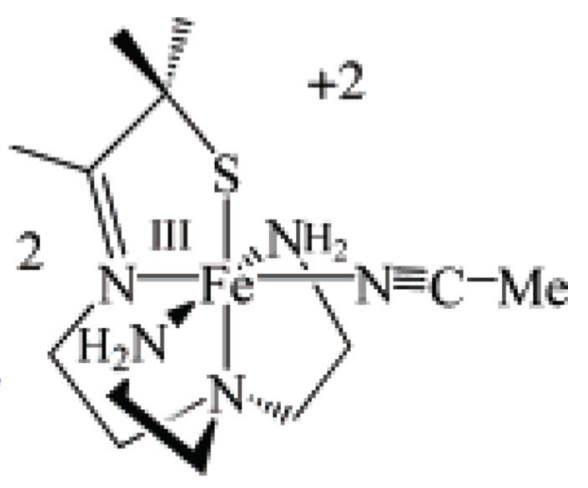


<smiles>CCCN(CCNCCN)CCN(CCNCCN)CCN(CC#N)CCN(CCN)CCNCCNCC</smiles>

Scheme 4. 
Table 1

Crystal Data for $\left[\mathrm{Fe}^{\mathrm{III}}\left(\mathrm{S}^{\mathrm{Me} 2} \mathrm{~N}_{4}(\text { tren })\right)\right]_{2}(\mu-\mathrm{O})(\mathrm{PF} 6)_{2} \bullet \mathrm{MeCN}(\mathbf{3})$ and $\left[\mathrm{Fe}^{\mathrm{II}}\left(\mathrm{S}^{\mathrm{Me} 2} \mathrm{~N}_{4}\left(\operatorname{tren}_{-}-\mathrm{Et}_{4}\right)\right)\right]\left(\mathrm{PF}_{6}\right)(\mathbf{5})$

\begin{tabular}{lll}
\hline & $\mathbf{3}$ & $\mathbf{5}$ \\
\hline formula & $\mathrm{C}_{24} \mathrm{H}_{53} \mathrm{~F}_{12} \mathrm{Fe}_{2}-\mathrm{N}_{9} \mathrm{OP}_{2} \mathrm{~S}_{2}$ & $\mathrm{C}_{19} \mathrm{H}_{41} \mathrm{~F}_{6} \mathrm{FeN}_{4} \mathrm{PS}$ \\
$\mathrm{MW}(\mathrm{g} / \mathrm{mol})$ & 949.51 & 558.44 \\
Temp (K) & $130(2)$ & $130(2)$ \\
unit cell ${ }^{a}$ & monoclinic & monoclinic \\
space group & $P{ }_{1} / c$ & $P c$ \\
$a(\AA)$ & $12.6470(9)$ & $8.4540(2)$ \\
$b(\AA)$ & $17.004(2)$ & $10.8940(3)$ \\
$c(\AA)$ & $36.359(5)$ & $14.4500(4)$ \\
$a(\mathrm{deg})$ & 90 & 90 \\
$\beta(\mathrm{deg})$ & 90 & $106.1270(19)$ \\
$\gamma(\mathrm{deg})$ & 90 & 90 \\
$V\left(\AA^{3}\right)$ & $7816.5(16)$ & $1278.44(6)$ \\
$Z$ & 8 & 2 \\
$\sigma_{\text {calc }}\left(\mathrm{mg} / \mathrm{m}^{3}\right)$ & 1.614 & 1.415 \\
$R^{b}$ & 0.1108 & 0.0406 \\
$R_{\mathrm{w}}$ & 0.2369 & 0.1074 \\
$\mathrm{GOF}$ & 0.949 & 1.091 \\
& &
\end{tabular}

${ }^{a}$ In all cases, $\operatorname{Mo~} \operatorname{Ka}(\lambda=0.71070 \AA)$ radiation was used.

$b_{R}=\Sigma|| F_{\mathrm{O}}|-| F_{\mathrm{C}}|/ \Sigma| F_{\mathrm{O}} \mid ; R_{\mathrm{W}}=\left[\Sigma w\left(\left|F_{\mathrm{O}}\right|-\left|F_{\mathrm{C}}\right|\right)^{2} / \Sigma w F_{\mathrm{O}}^{2}\right]^{1 / 2}$, where $w^{-1}=\left[\sigma^{2}\right.$ count $\left.+\left(0.05 F^{2}\right)^{2}\right] / 4 F^{2}$. 


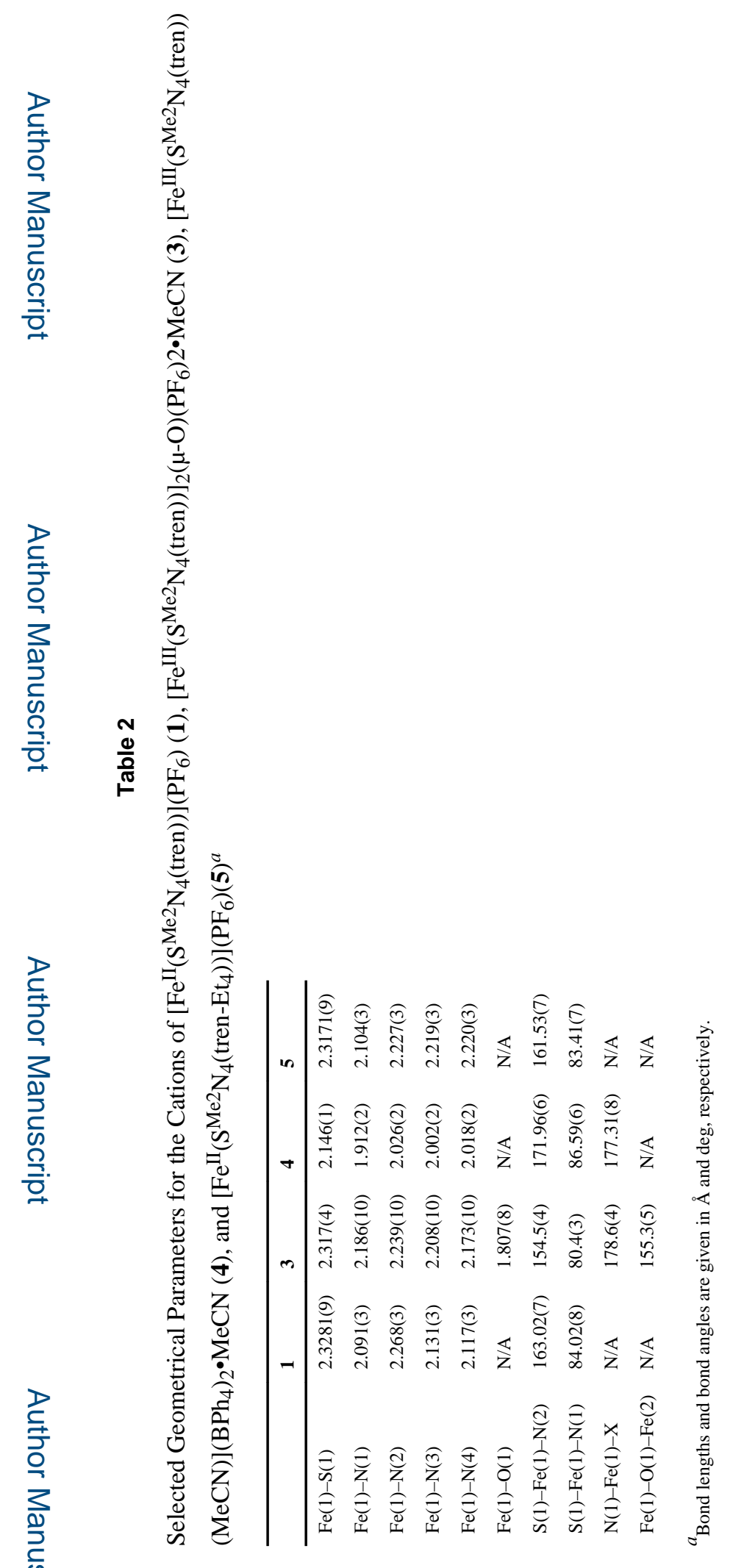

